\title{
21. MAGNETOSTRATIGRAPHY OF SITES 703 AND 704, METEOR RISE, SOUTHEASTERN SOUTH ATLANTIC 1
}

\author{
E. A. Hailwood ${ }^{2}$ and B. M. Clement ${ }^{3}$
}

\begin{abstract}
ODP Sites 703 and 704 were drilled near the crest of the Meteor Rise in the southeastern part of the South Atlantic in order to explore the role of this aseismic rise as a barrier to the flow of deep water between the Antarctic and South Atlantic during the early evolution of the South Atlantic and to investigate the subsequent subsidence and paleoceanographic evolution of this area.

A combination of shipboard whole-core paleomagnetic determinations on all archive core halves and post-cruise paleomagnetic analyses of some 440 discrete samples from the two sites has allowed definition of the sequence of geomagnetic polarity reversals that occurred during deposition of much of this sedimentary sequence. The magnetostratigraphic record for Sit: 703 extends from the middle Eocene to the early Miocene and that for Site 704 from the early Miocene to the Pleistocene. The correlation of this record to the standard geomagnetic polarity time scale of Berggren et al. (1985) is generally good for the Oligocene and late Miocene to Pleistocene, but is poorer for the early and middle Miocene.

The combined magnetostratigraphic record for these two sites will facilitate the development and chronometric calibration of refined high-latitude biostratigraphic zonations. Furthermore, it provides an important basis for defining the periodicity of the late Neogene stable isotope and carbonate fluctuations observed in these cores and relating these changes to the paleoclimatic and paleoceanographic driving forces.
\end{abstract}

\section{INTRODUCTION}

The southern South Atlantic Ocean basin began to develop by rifting and seafloor spreading between western Africa and eastern South America in the Early Cretaceous (e.g., Lawver et al., 1985). During the early stages of opening, deep-water connections between the Antarctic and developing South Atlantic oceans were inhibited by the topographic barrier formed by the Falkland and Agulhas plateaus and associated fracture zones. These fracture zones were generated by transform fault motion across a major offset in the spreading-ridge axis. The first stage in the breech of this topographic barrier occurred in the Late Cretaceous and involved a westerly shift, through some $1000 \mathrm{~km}$, of the spreading-ridge axis (Fig. 1A). This led to the generation of a major volcanic edifice along the site of the new spreading axis (LaBrecque and Hayes, 1979). Continued lateral migration of the oceanic lithosphere away from the spreading axis resulted in the splitting of this volcanic edifice and the lateral transport of one part (the Islas Orcadas Rise) to the west and the other part (the Meteor Rise) to the east (Fig. 1B). The widening gateway between these two structures provided the first major deep-water connection between the Antarctic and South Atlantic ocean basins and its development had profound effects on world oceanic circulation patterns and climatic conditions.

A major objective of Ocean Drilling Program (ODP) Leg 114 was to investigate the history of formation of this gateway, by exploring the paleobathymetry and changing oceanic environment documented in the sedimentary record of one site located within the "gateway" (Site 701), one site on the

\footnotetext{
${ }^{1}$ Ciesielski, P. F., Kristoffersen, Y., et al., 1991. Proc. ODP, Sci. Results, 114: College Station, TX (Ocean Drilling Program).

${ }^{2}$ Department of Oceanography, University of Southampton, SO9 5NH, UK.

${ }^{3}$ Ocean Drilling Program, Texas A\&M University, 1000 Discovery Drive, College Station, TX 77845-9547 (Present address: Department of Geology, Florida International University, College of Arts \& Sciences, University Park, Miami, FL 33199).
}

western portal formed by the Islas Orcadas Rise (Site 702), and two sites on the eastern portal formed by the Meteor Rise (Sites 703 and 704). At all four sites a full interpretation of the sedimentary record requires establishing a precise stratigraphic framework, in order to determine with the maximum possible precision the timing of the tectonic, paleoceanographic, and paleoclimatic events deduced from this record. This stratigraphic framework has been provided by a combined biostratigraphic and magnetostratigraphic investigation of the sedimentary sequences recovered.

The present paper describes the paleomagnetic measurements carried out to establish a magnetostratigraphic zonation for the sediment recovered at Sites 703 and 704 on the Meteor Rise. Age-calibrated biostratigraphic datums defined in these sediments are used to correlate the observed sequence of magnetic polarity zones (magnetozones) to the standard geomagnetic polarity time scale (GPTS) of Berggren et al. (1985). In this way a set of precisely defined "time planes" (the geomagnetic polarity chron boundaries) is provided for each site. The establishment of this time framework allows the time-calibration of new high-latitude biostratigraphic zonations defined in these sediments and has particular value in the interpretation of the carbonate and stable isotope records observed in the rapidly deposited late Neogene age sediments at Site 704.

The magnetostratigraphy for the associated Sites 701 and 702 is described by Clement and Hailwood (this volume).

\section{PALEOMAGNETIC MEASUREMENTS}

Paleomagnetic determinations on the sediments from Sites 703 and 704 were carried out using (1) the shipboard three-axis whole-core cryogenic (WCC) magnetometer (manufactured by $2 \mathrm{G}$ Enterprises) and (2) the discrete-sample cryogenic (DSC) dual-axis magnetometer system (manufactured by Cryogenic Consultants Ltd.) in the Southampton University paleomagnetic laboratory. The WCC magnetometer was used to make paleomagnetic measurements at $10-\mathrm{cm}$ intervals along the length of all archive core halves, whilst the DSC 

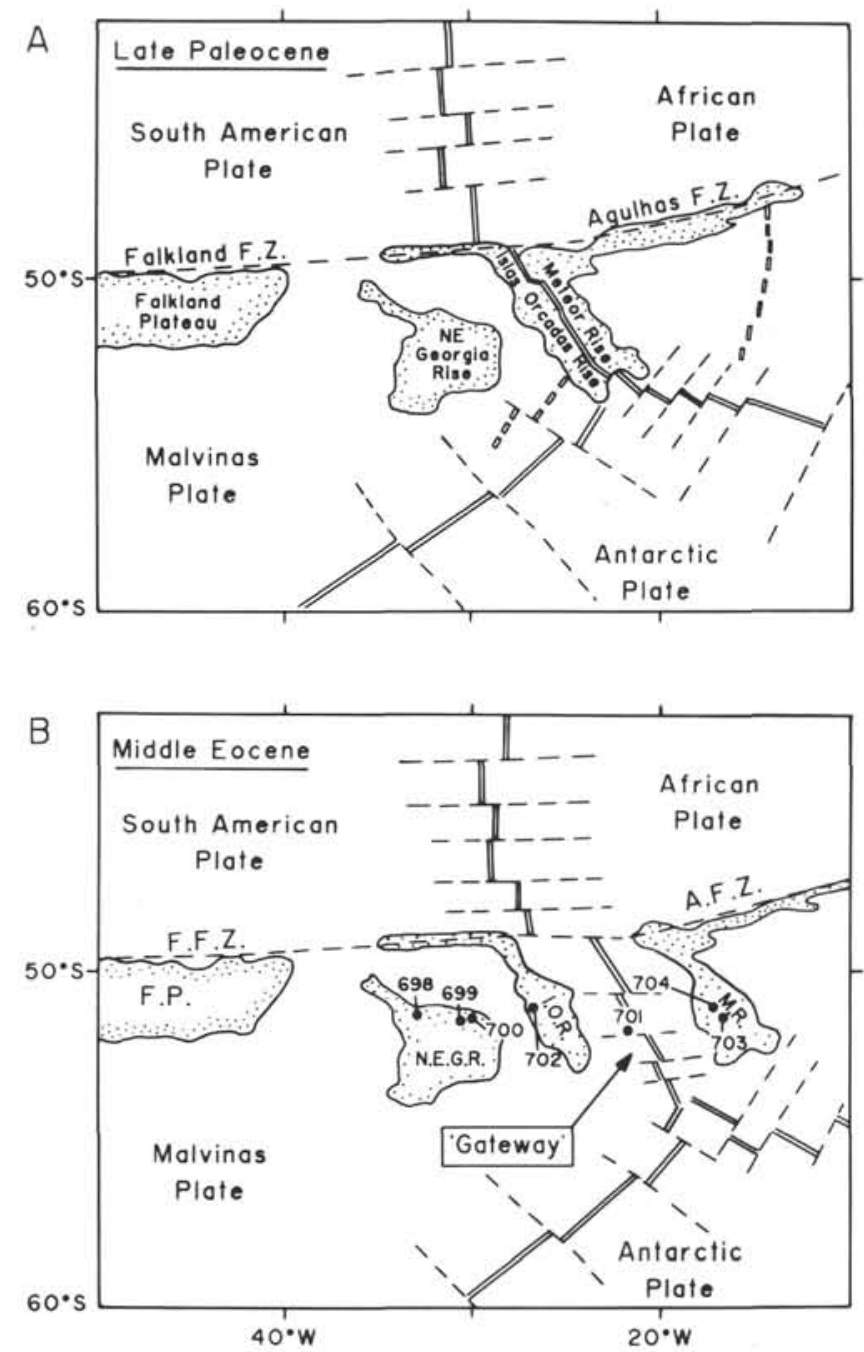

Figure 1. Plate tectonic reconstructions of the southern South Atlantic region for (A) the late Paleocene and (B) the middle Eocene (from LaBrecque, 1986). Topographic highs are shaded. The positions of ODP Leg 114 drill sites are labeled. Active and former (extinct) spreading axes are indicated by continuous and broken double lines, respectively. Transform faults and fracture zones are shown by dashed lines.

system was used for discrete specimens contained in standard $6-\mathrm{cm}^{3}$ ODP paleomagnetic sample boxes. Normally either one or two discrete samples were taken from each $1.5-\mathrm{m}$ core section. The stability of the magnetism was tested and lowstability (low-coercivity) components of magnetic remanence were removed by incremental alternating field (AF) demagnetization. This was carried out on the WCC system using a three-axis AF demagnetizer mounted in line with the WCC magnetometer and capable of producing a maximum field of 9 $\mathrm{mT}$. The discrete samples were analyzed by means of a three-axis AF demagnetizer incorporated into the Southampton University DSC system, with a maximum field capability of $35 \mathrm{mT}$.

\section{SEDIMENTS}

At Site 703 one hole (703A) was drilled on the slope of a basement peak on the Meteor Rise using the advanced hydraulic piston corer (APC) to a depth of $137.9 \mathrm{~m}$ below seafloor (mbsf) and then the extended core barrel (XCB) corer to a total depth of $377.4 \mathrm{mbsf}$. Core recovery in the upper 190 $\mathrm{m}$ averaged $85 \%$, but below this depth was very poor, averaging only $16 \%$. At this site a thin $(\sim 10 \mathrm{~m})$ unit of Quaternary to late Pliocene age nannofossil oozes is separated by a hiatus from an underlying sequence of early Miocene to middle Eocene age calcareous ooze and chalk, overlying basaltic basement at $364 \mathrm{mbsf}$. This sequence represents a single lithofacies and has been subdivided into four lithostratigraphic subunits on the basis of minor changes in lithology and degree of diagenesis. The upper two of these (Subunit IA, 0-71.4 mbsf, Quaternary to early Oligocene age, and Subunit IB, 71.4-162.4 mbsf, early Oligocene to middle Eocene age) are dominantly foraminifer-bearing nannofossil oozes and appear to be autochthonous. The lower two (Subunit IC, 162.4-228.9 mbsf, and Subunit ID, 228.9-371.9 mbsf), both middle Eocene in age, contain mass-flow deposits of clay, foraminifer ooze, and gravel. They show a downward gradation from nannofossil ooze in Subunit IC to nannofossil chalk in Subunit ID. The presence of these mass-flow deposits, together with significant drilling disturbance and the generally poor recovery below 190 mbsf, rendered Subunits IC and ID unsuitable for magnetostratigraphic studies. Consequently, paleomagnetic analyses were restricted to Subunits IA and IB.

The major tectonic objectives of drilling on the Meteor Rise were achieved by drilling to basement at Site 703 . Consequently, the associated Site 704 was located on a part of the Meteor Rise where a particularly thick sequence of Neogene and upper Paleogene sediments could be cored in order to provide a high-resolution paleoceanographic-paleoclimatic record for this time interval. Two holes were drilled at Site 704, using the APC system for the upper 140 to $150 \mathrm{~m}$ and the XCB system beneath this. Hole 704A penetrated $283 \mathrm{~m}$ of Quaternary to late Miocene age sediments, and Hole 704B extended this record through an additional $390 \mathrm{~m}$ of late Miocene to early Oligocene age deposits. These sediments were divided into two principal lithostratigraphic units, Unit I (0-451 mbsf), consisting of oozes of varying siliceous and calcareous composition, and Unit II (451-672 mbsf), comprising white chalks. The Neogene sequence at this site is the thickest and most complete section yet drilled at high southern latitudes.

\section{MAGNETIC INTENSITY}

As discussed in the accompanying paper by Hailwood and Clement (this volume), a number of factors, including incomplete filling of the core liner, variations in the thickness of the archive core half, and the presence of drilling slurry between the core and the liner, contributes to limiting the reliability of determinations of magnetic intensity using the WCC system. Consequently, analyses of natural remanent magnetization (NRM) intensity in this paper are based only on DSC measurements. The variations of NRM intensity with depth at Sites 703 and 704 are summarized in Table 1 and shown in Figures 2 and 3, respectively.

Table 1. Mean NRM intensity values, Sites 703 and 704.

\begin{tabular}{ccc}
\hline Site & $\begin{array}{c}\text { Depth interval } \\
(\mathrm{mbs})\end{array}$ & $\begin{array}{c}\text { Log mean intensity } \\
(\mathrm{mA} / \mathrm{m})\end{array}$ \\
\hline 703 & $0-81$ & $1.026 \pm 1.325$ \\
704 & $81-272$ & $0.231 \pm 0.295$ \\
& $10-130$ & $0.137 \pm 0.127$ \\
& $130-250$ & $2.430 \pm 5.226$ \\
& $250-480$ & $0.111 \pm 0.177$ \\
& $480-650$ & $0.992 \pm 0.165$ \\
\hline
\end{tabular}

a \pm standard deviation. 


\section{NRM intensity $(\mathrm{mA} / \mathrm{m})$}

Lith.

unit
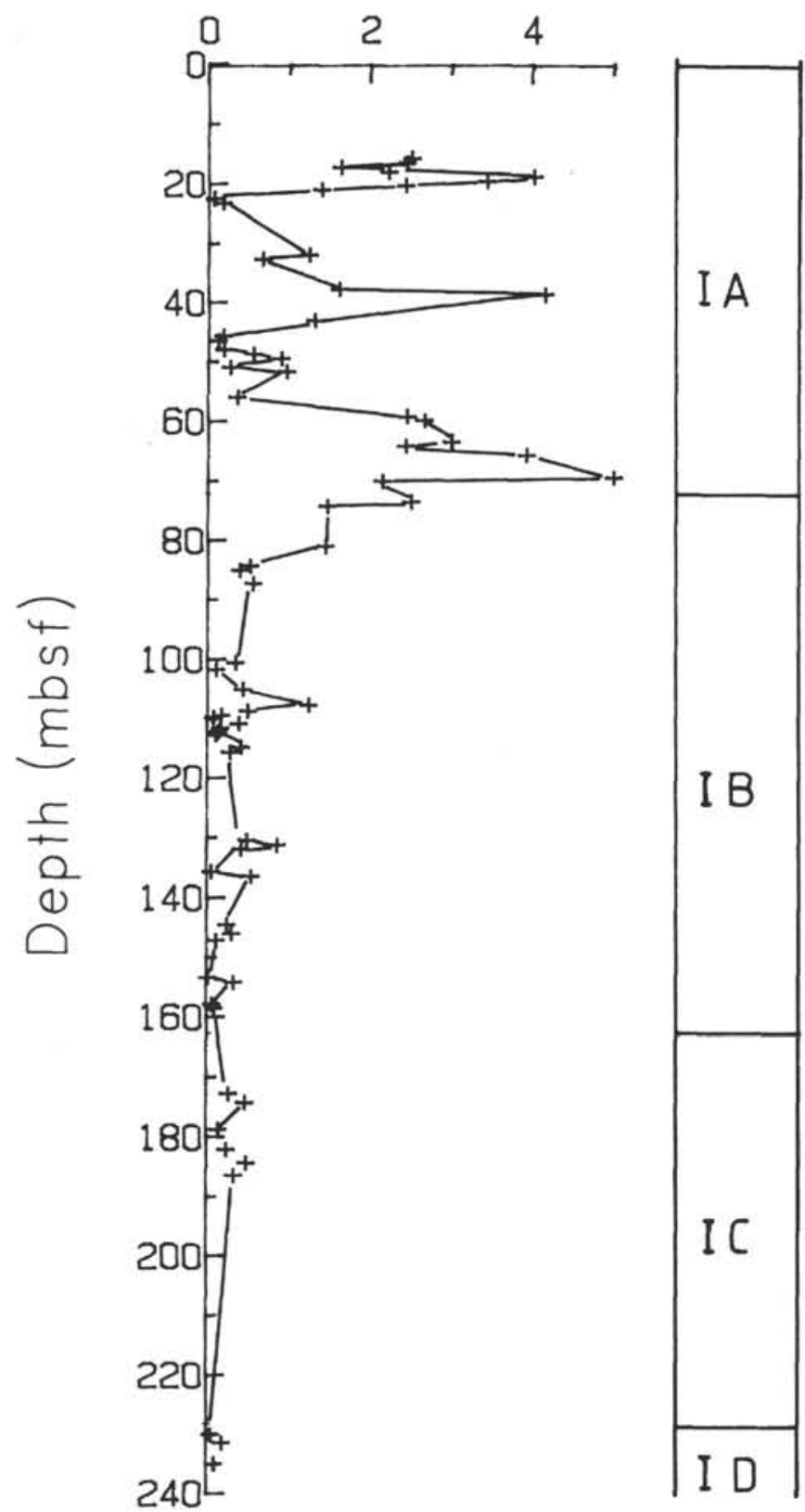

Figure 2. Variation of NRM intensity with depth in Hole 703A, determined from discrete sample measurements. Principal lithostratigraphic unit boundaries are shown.

At Site 703 there is a marked decrease of NRM intensity at a depth of about $81 \mathrm{mbsf}$. The zone of decrease lies near to the boundary between lithostratigraphic Subunits IA and IB (Fig. 2).

At Site 704 the NRM intensities show similar variations in the two holes (Fig. 3A). The values for the calcareous and siliceous oozes of lithostratigraphic Subunit IA and the upper part of Subunit IB are particularly weak, as also are those for the diatom-bearing nannofossil oozes of Subunit ID and the nannofossil chalks of Subunit IIA (Fig. 3B). In contrast, the mean values for the lower part of Subunit IB and the whole of
Subunits IC and IIB are about an order of magnitude higher. Results of isothermal remanent magnetization (IRM)-acquisition analyses on representative samples from the two sites are shown in Figure 4. The left column of plots relates to samples with weak NRM intensities and the right column to samples with strong NRM intensities. In all cases the magnetization nearly or completely saturates in an applied field of about 0.3 $\mathrm{T}$, indicating that the dominant magnetic mineral in all of these sediments is magnetite. The observed variations in magnetic intensity therefore must be attributed to variations in the amount and possibly also the grain size of this mineral.

The upper $100-\mathrm{m}$ section of sediment at Site 704 was very soft and water saturated, and it is possible that the weak magnetic intensities in this interval may, in part, reflect the relatively high porosities of these sediments. However, the relatively abrupt change in magnetic intensity at a depth of 130 mbsf (Fig. 3) does not appear to correspond with a significant change in wet-bulk density or sonic velocity values (Nobes et al., this volume). Furthermore, this explanation could not account for the other, deeper interval of weak NRM intensity from 240 to 480 mbsf, which extends from nannofossil oozes down into indurated chalks. As with the magnetic intensity fluctuations observed at other Leg 114 sites (Hailwood and Clement, this volume), it is concluded that the changes at Sites 703 and 704 are due mainly to fluctuating inputs of magnetite derived either from terrigenous sources or from magnetotactic bacteria inhabiting the microaerobic environment of the seafloor sediments. A measure of the terrigenous flux to this area is provided by the gamma-ray logs run in this hole, which reflect the total clay mineral content of the sediment. These logs show no discernable changes at the magnetic intensity "boundaries" (130, 250, and $480 \mathrm{mbsf})$. It is concluded that fluctuations in bacterially produced magnetite provide the most satisfactory explanation for the magnetic intensity change. Because these bacteria secrete magnetite only in a very limited range of oxygen saturation values $(3 \%-5 \%)$, the observed intensity fluctuations may represent a sensitive indicator of changes in oxic conditions at the sediment/water interface.

\section{MAGNETIC STABILITY AND RELIABILITY OF PALEOMAGNETIC OBSERVATIONS}

The principal aim of the paleomagnetic investigations carried out on these sediments was to establish the polarity of the characteristic component of stable remanent magnetism that they carry. This magnetization normally becomes fixed in the sediment during, or very soon after, the depositional process and thus provides a record of the geomagnetic field polarity at this time. However, the direction of the remanent magnetism may deviate from the geomagnetic field vector at the time of deposition for a number of reasons. First, the sediments may acquire a secondary magnetic overprint, which is superimposed on the primary component, at a later stage in their history. Commonly, this may be a viscous remanent magnetization (VRM) acquired in the present geomagnetic field at the drill site. Such components usually are magnetically "soft" and can be removed by AF demagnetization in relatively weak applied fields. Second, the sediment may be disturbed during drilling, core splitting, and/or subsampling, and this may either modify the original primary magnetization or replace it by a new component.

In this section observations of magnetic stability and sampling-induced components are discussed. In this study the polarity of the remanent magnetization was deduced from the magnetic inclination values, which at these high-latitude Southern Hemisphere sites should have steep negative values 


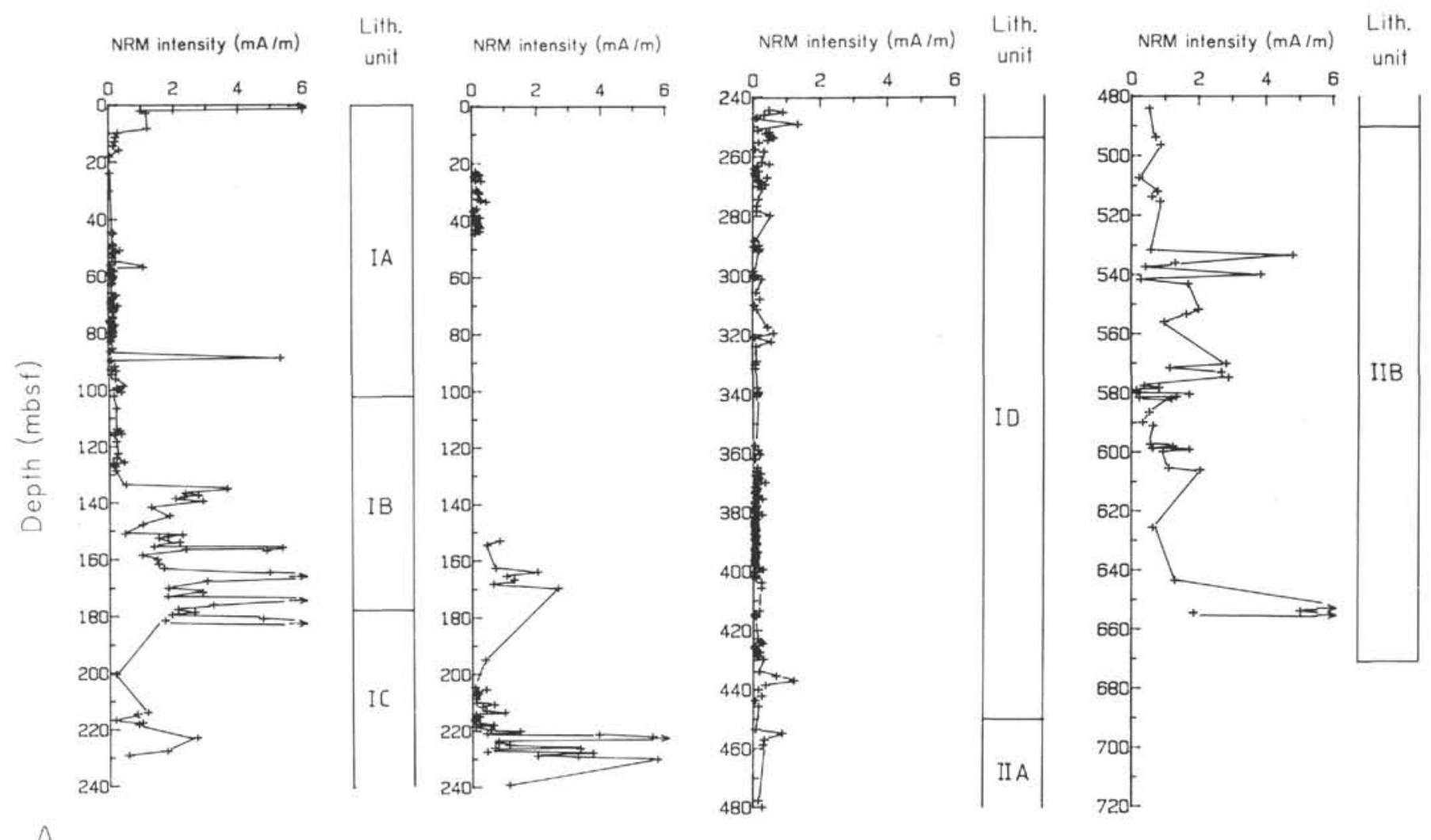

B

Figure 3. Variation of NRM intensity with depth in the (A) upper $240 \mathrm{~m}$ of Holes 704A and 704B and (B) lower part of Hole 704B. Principal lithostratigraphic unit boundaries are shown.

for normal polarity and steep positive values for reverse polarity magnetizations. The magnetic declination values cannot be used in these polarity assignments because the XCB cores are unoriented and because of problems with the APC orientation system during Leg 114.

\section{AF Demagnetization}

All archive core halves (with the exception of those showing clear indication of significant drilling disturbance) were measured on the shipboard WCC magnetometer, in their "natural" state and also after partial demagnetization in a peak alternating field of 5 or $9 \mathrm{mT}$. Commonly this AF demagnetization caused only small changes $(<5 \%)$ in the direction and intensity of remanent magnetization.

To further investigate the magnetic stability of these sediments and to confirm that the WCC analyses provide a reliable determination of the succession of normal and reverse polarity magnetozones present, all 440 discrete samples from Sites 703 and 704 were subjected to incremental AF demagnetization using the Southampton University DSC system. Because of the very weak magnetic intensities of a high proportion of these samples, AF demagnetization in relatively low applied fields $(<10 \mathrm{mT})$ reduced the intensity to a value close to the magnetometer noise level $(\sim 0.03 \mathrm{~mA} / \mathrm{m})$ so that further reliable paleomagnetic measurements were not possible. For this reason $65 \%$ of the samples could be demagnetized only up to about $10 \mathrm{mT}$. The other $45 \%$ was demagnetized in maximum fields in the range of 20 to $35 \mathrm{mT}$.

Examples of the response to this treatment of typical samples from Sites 703 and 704 are shown on Zijderveld diagrams in Figures 5 and 6, respectively. In these diagrams the end point of the paleomagnetic vector after each demag- netization step is plotted on a vertical plane (open symbol) and a horizontal plane (solid symbol) (Zijderveld, 1967). When only a single component of magnetization remains in the sample these points lie on a pair of linear segments directed through the origin. Figure $5 \mathrm{~A}$ shows typical results for the high-intensity sediments of lithostratigraphic Subunit IA in Hole 703A and Figure 5B illustrates results for the more weakly magnetic sediments of Subunit IB. In all cases small to moderate changes in the direction of remanent magnetism occur during demagnetization up to $5-10 \mathrm{mT}$, but thereafter the trajectories are generally directed toward the origin. This behavior indicates the removal of a magnetically soft component during low-field AF demagnetization and the isolation of a more stable characteristic component of magnetization. The latter component is generally well-defined in the more strongly magnetic samples, but more random noise is present on the plots for the weakly magnetic specimens. The behavior of the reverse polarity Samples 114-703A-4H-6, $51 \mathrm{~cm}$, and 114$703 \mathrm{~A}-8 \mathrm{H}-2,46 \mathrm{~cm}$, is similar to that of the normal polarity samples (Fig. 5).

The response to AF demagnetization of the samples from Site 704 (Fig. 6) is essentially the same as that of the samples from Site 703 (Fig. 5).

\section{Magnetic Declination and Sampling Disturbances}

During coring with the APC system the core barrel is hydraulically fired ahead of the stationary drill pipe, thereby freeing the sediment core from the mechanical disruption commonly produced by rotary drilling. The fiducial line scribed along the length of the plastic core liner has an arbitrary azimuthal orientation during APC firing (Fig. 7). Had the orientation camera functioned correctly, the azimuth of 


\section{$703 \lambda$}

$20.2 \mathrm{~mA} / \mathrm{m}$

$544.7 \mathrm{~mA} / \mathrm{m}$
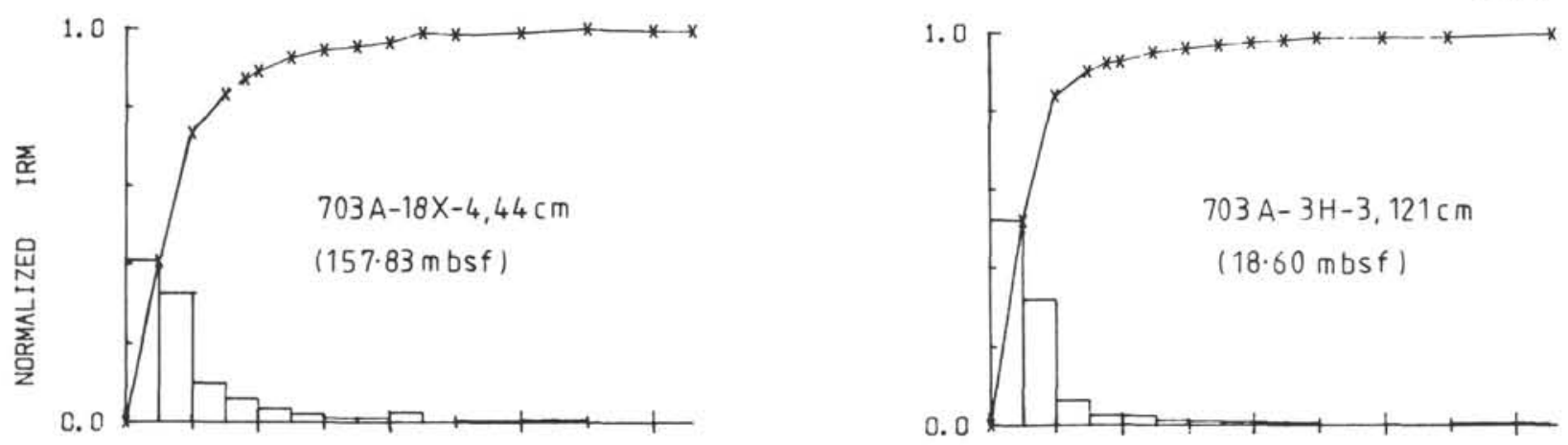

\section{$704 A$}

$11 \quad m \wedge / m$

$1143 \mathrm{~mA} / \mathrm{m}$
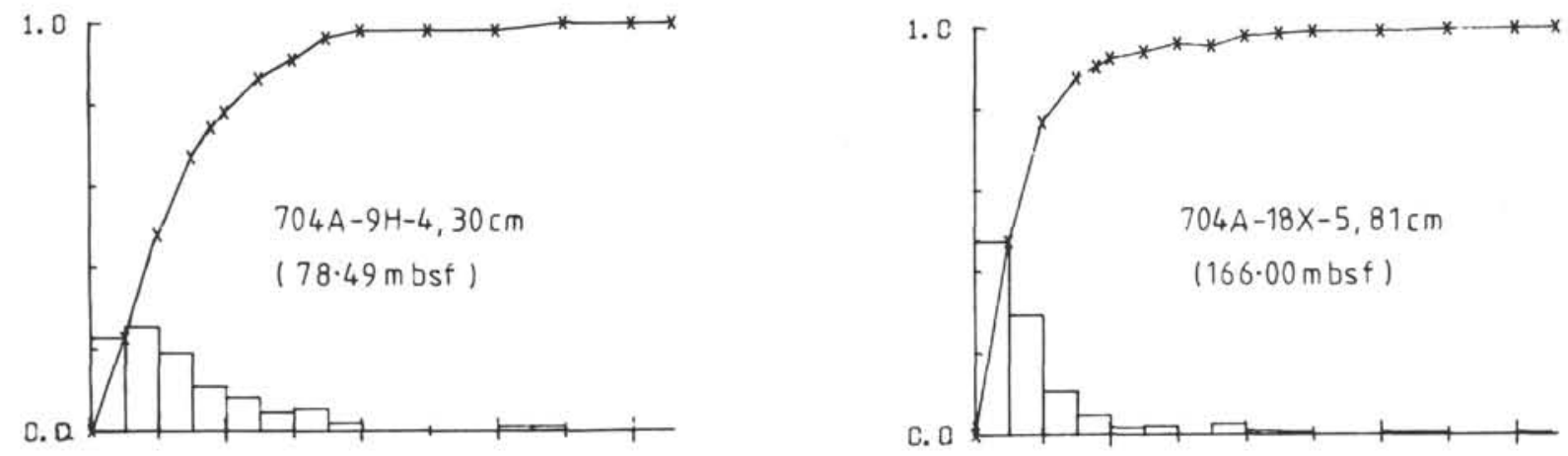

\section{$704 \mathrm{~B}$}

28. $9 \mathrm{~mA} / \mathrm{m}$
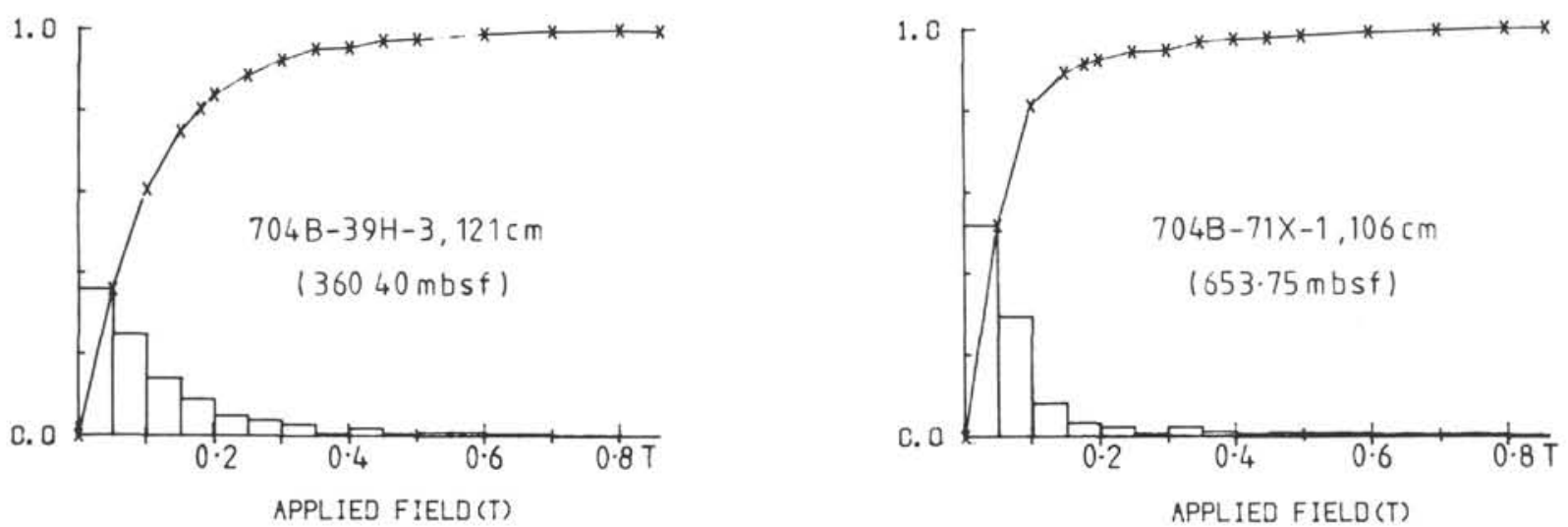

Figure 4. Examples of results of IRM-acquisition analyses for representative samples from Sites 703 and 704. In these analyses the samples are progressively magnetized by the application of a direct field of intensity up to $0.9 \mathrm{~T}$. The resulting growth of IRM (normalized by the maximum value) is plotted against the applied field (crosses). A histogram of the IRM acquired for each successive field increment is also shown, and the maximum IRM value is given. 


$$
\begin{gathered}
\text { Somple } \\
\text { 114-703A-3H-3, 46cm }
\end{gathered}
$$

Scole: $\mid$ unit $=0.249 \mathrm{~mA} / \mathrm{m}$

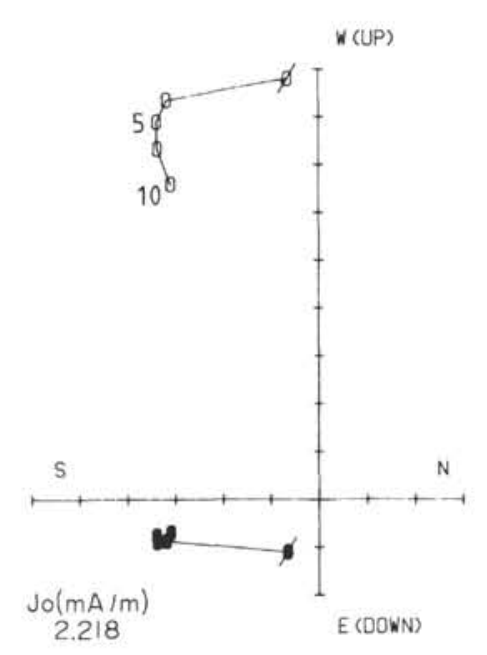

Somple
$114-703 \mathrm{~A}-74-4,56 \mathrm{~cm}$ Scole: 1 unit $=0.111$

A

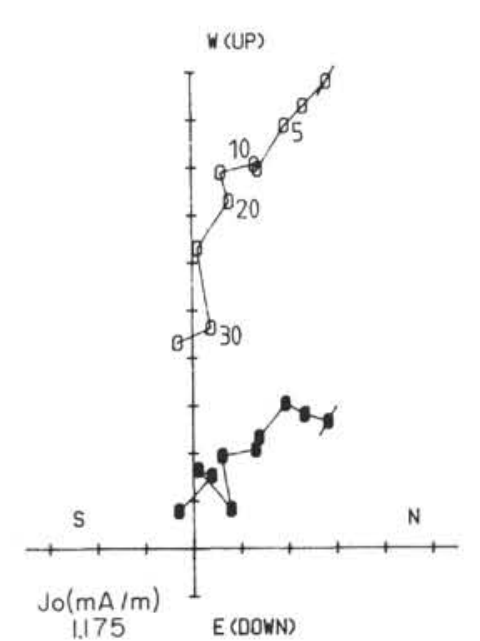

Somple

114-703A-4H-6, $51 \mathrm{~cm}$

Scole: 1 unit $=0.126$

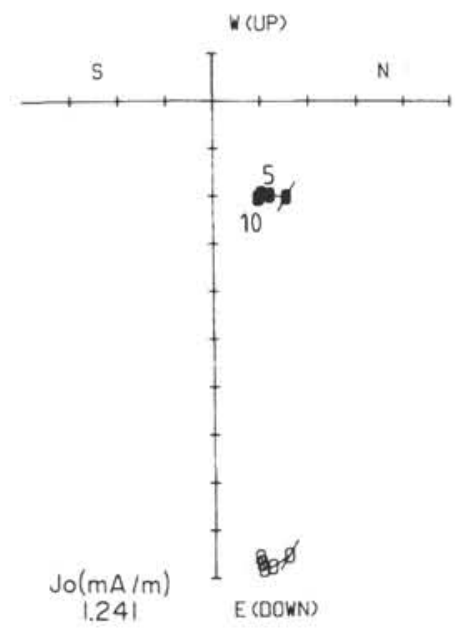

Sample
114-703A-8H-2, 46cm

Scole: $\mid$ unit $=0.255$

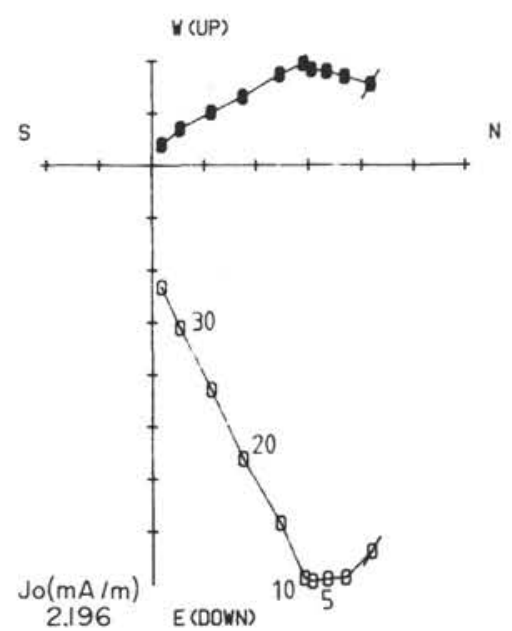

Somple
114-703A-13H

114-703A-13H-2, $124 \mathrm{~cm}$ Scole: I unit $=0.014 \mathrm{~mA} / \mathrm{m}$

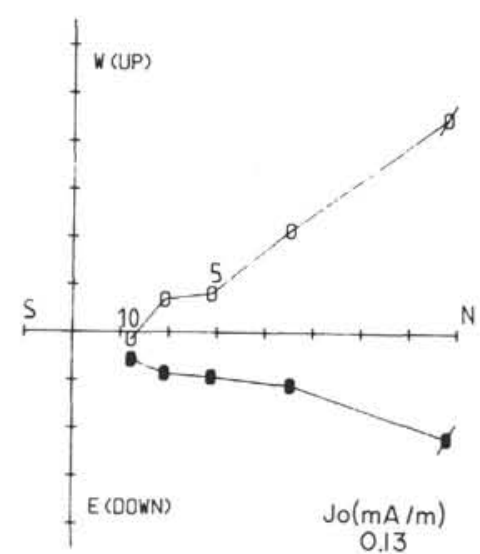

Somple
114-703A-26X-2, $10 \mathrm{lcm}$ Scole: 1 unit $=0.016$

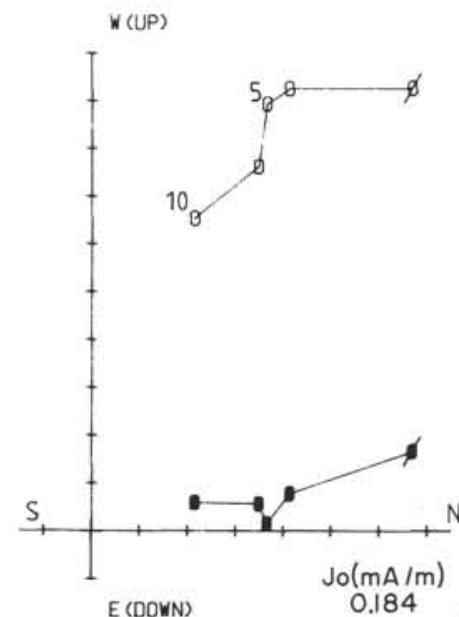

Somple

14-703A-20X-2, 75cm

Scole: 1 unit $=0.063$

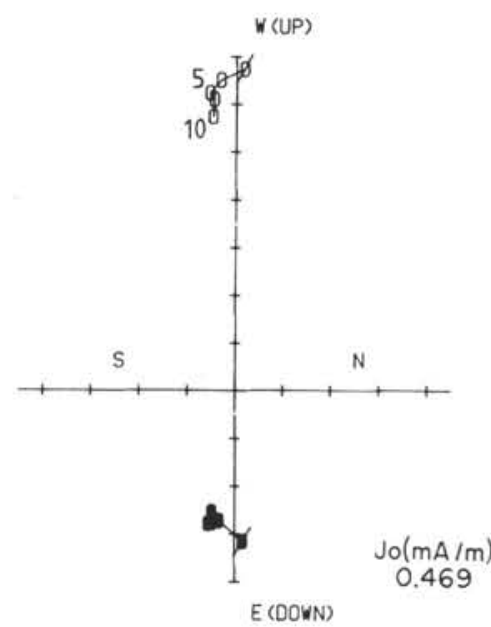

E (DOWN)
114-703A-15X-4, 46cm

Scole: 1 unit $=0.040$

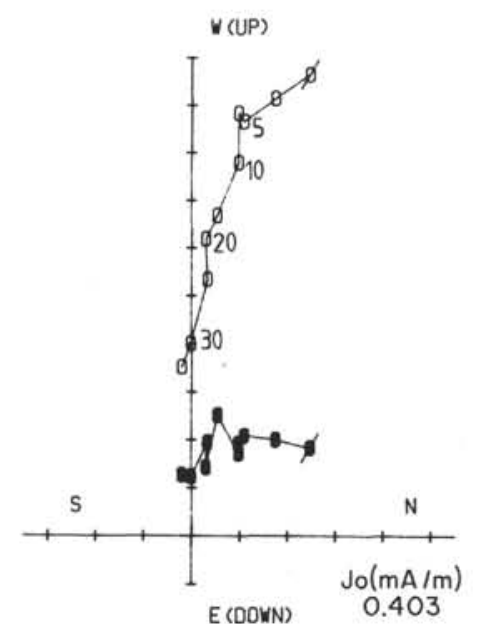

Figure 5. Response to AF demagnetization of typical discrete samples from Hole 703A. For each sample the paleomagnetic vectors are plotted on a pair of orthogonal planes with a common horizontal axis. Open symbols represent points on the vertical plane and solid symbols points on the horizontal plane. $\mathrm{J}_{\mathrm{o}}$ is the initial (NRM) intensity. The numbers next to the points refer to the demagnetizing field intensity in milliTeslas. Note that $N, E, S$, and $W$ refer to an arbitrary reference azimuth, because the cores are not oriented. A. High-intensity samples from above 80 mbsf. B. Low-intensity samples from beneath 80 mbsf. 
Sample

114-704A-3H-5, 99cm

Scale: I unit $=0.004 \mathrm{~mA} / \mathrm{m}$

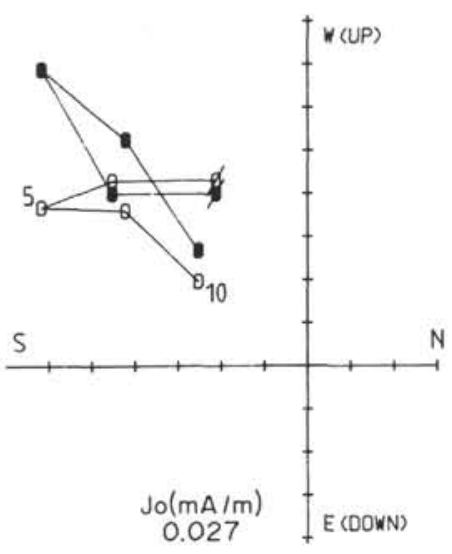

Somple

$14-704 A-18 X-1,81 \mathrm{~cm}$

Scole: 1 unit $=0.150$

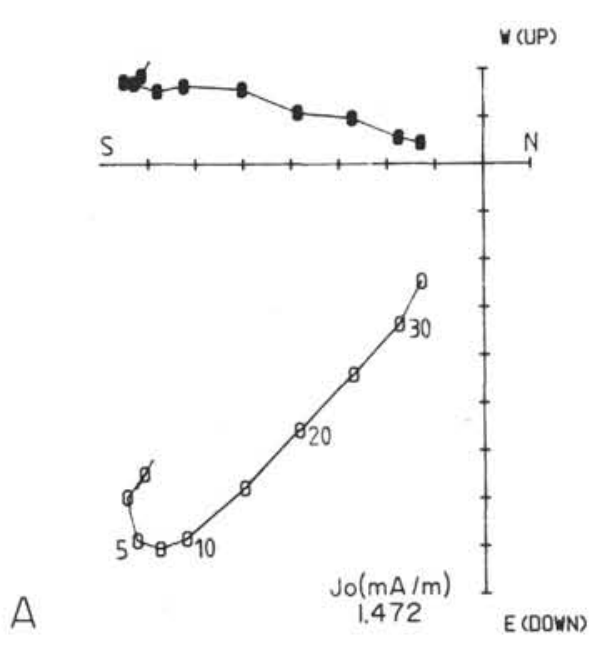

Sample

114-704A-13H-2, $115 \mathrm{~cm}$

Scale: $\mid$ unit $=0.029$

v(UP)

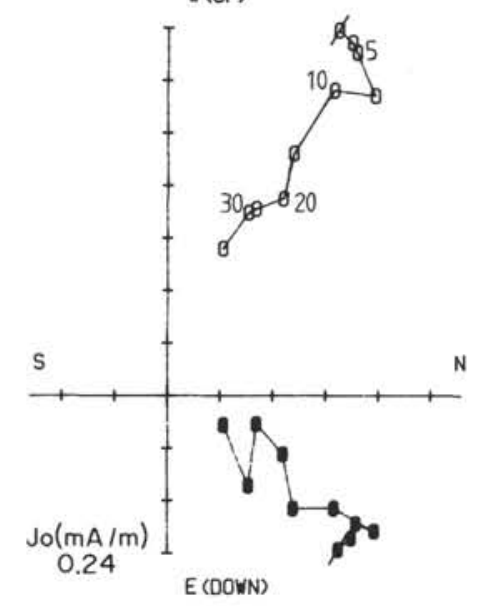

Somple

114-704A-19X-5, $126 \mathrm{~cm}$

Scale: 1 unit $=0.385$

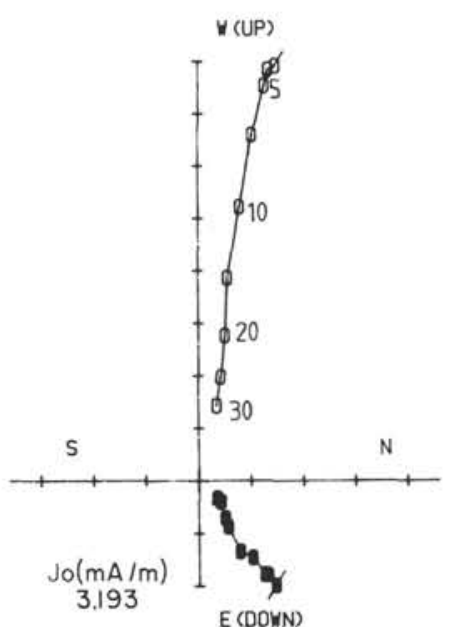

Sample

114-704B-4H-3, $27 \mathrm{~cm}$

Scale: 1 unit $=0.013 \mathrm{~mA} / \mathrm{m}$

(UP)

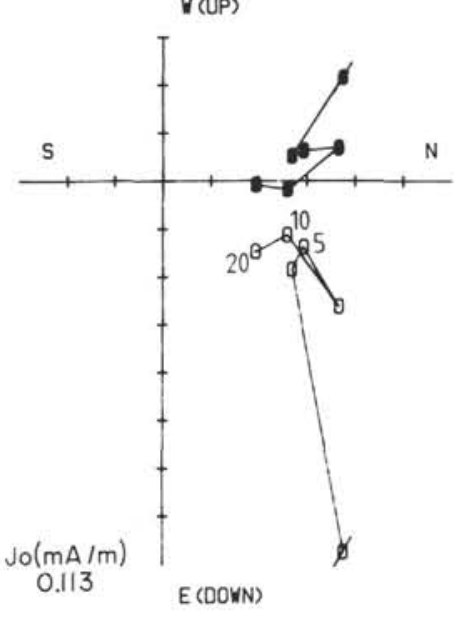

Sample

$114-704 \mathrm{~B}-53 \mathrm{X}-2,116 \mathrm{~cm}$ Scole: 1 unit $=0.027$

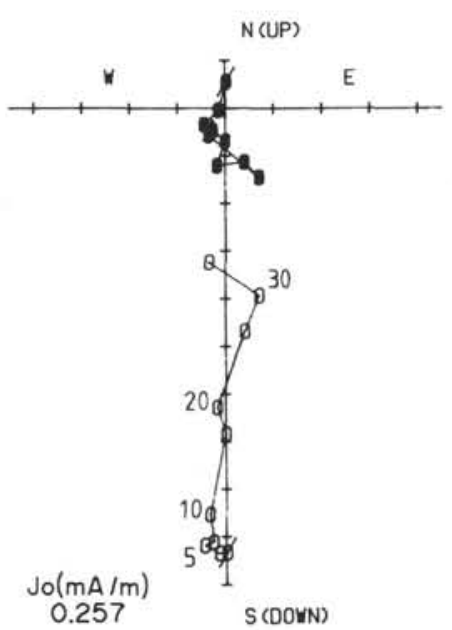

Somple

114-704B-40X-4, 31cm Scole: 1 unit $=0.018$

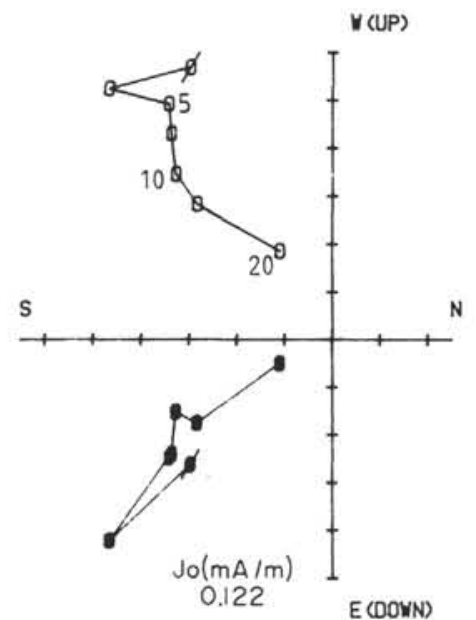

Somple

$114-704 \mathrm{~B}-35 \mathrm{H}-5,121 \mathrm{~cm}$ Scole: I unit $=0.055$

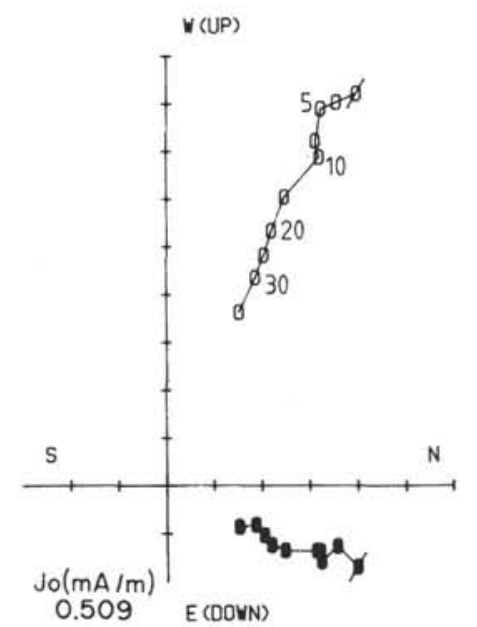

Figure 6. Response to AF demagnetization of typical discrete paleomagnetic samples from (A) Hole 704A and (B) Hole 704B. For an explanation of symbols and conventions see Figure 5. 


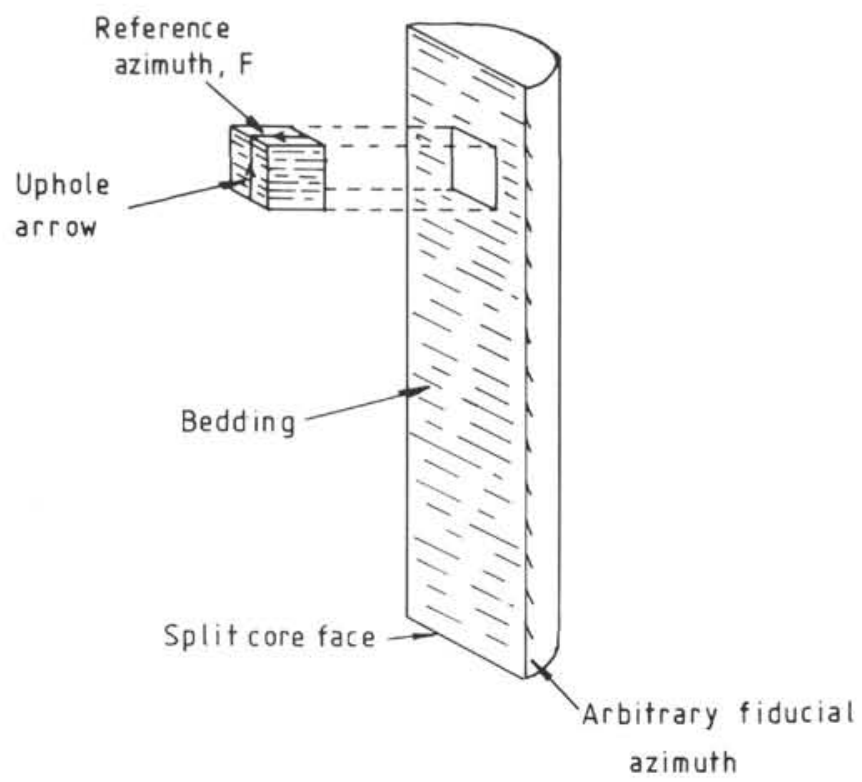

Figure 7. Paleomagnetic discrete sampling. The reference azimuth, $F$, is perpendicular to the split face of the core.

this fiducial line relative to magnetic north would have been specified. Aboard ship the liner is cut longitudinally along the fiducial line, which thus defines the azimuth of the split-core surface. Paleomagnetic samples are taken by pushing rectangular plastic sampling boxes into this split-core surface, with the reference axis of the sample box perpendicular to the original fiducial line. The declination of the remanent magnetism is specified relative to this reference axis. Consequently, it is to be expected that the declination values will be similar for all samples taken from the same core, but will differ from one core to another.

The declination values obtained from all discrete sample measurements on APC cores and XCB cores are plotted separately on circular histograms (rose plots) for Hole 704A in Figure 8 and Hole 704B in Figure 9. The XCB cores show the expected random distribution of declination values. Thus, data for only three XCB cores are available for Hole 704A, but each of these shows its own distinct declination mode (Fig. $8 \mathrm{~B})$. Similarly, the declination values for all $23 \mathrm{XCB}$ cores from Hole 704B show the expected wide range (Fig. 9B). However, this is not the case for the APC cores. The declination values for the 16 APC cores sampled from Hole $704 \mathrm{~A}$ show a pronounced clustering around an azimuth of $180^{\circ}$, whilst those for the three APC cores sampled from Hole $704 \mathrm{~B}$ show a clustering around an azimuth of $360^{\circ}$.

It is clear that the declination values for the APC cores are systematically aligned along the arbitrary reference axis (perpendicular to the split face of the cores) and therefore cannot represent true records of the paleomagnetic field declination. Instead, they are believed to reflect a modification of the original horizontal component of remanence (which is very weak at these relatively high magnetic latitudes) during cutting or subsampling of the cores. It is significant that the direction of the horizontal component of magnetization is aligned along the axis of "push" of the discrete sample boxes into the sediment core. This phenomenon was originally noticed during sampling of soft clays by Gravenor et al. (1984) and subsequently has been documented from a wide range of soft marine sediments taken with gravity, piston, and Kasten corers (Løvlie et al., 1986; Hailwood et al., 1989). The exact mechanism by which the sediment becomes remagnetized is
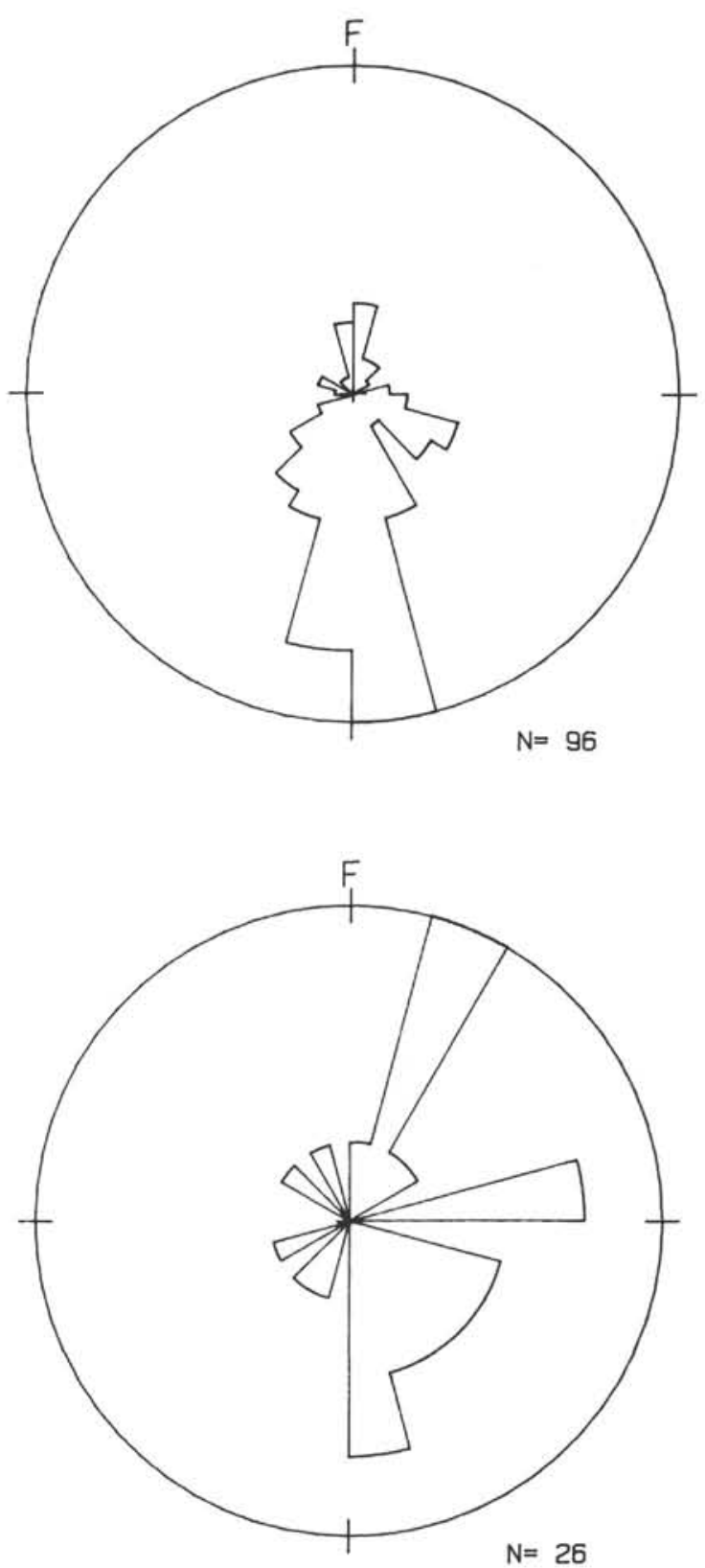

Figure 8. Circular histogram showing the distribution of paleomagnetic declination values for discrete samples from Hole 704A (after removal of low-stability components by AF demagnetization). The reference azimuth, $F$, is perpendicular to the split face of the core (see Fig. 7). A. Samples from APC cores. B. Samples from XCB cores.

still uncertain, but it is likely to involve a mechanical realignment of the magnetic grains caused by the shearing action during insertion of the sample box. Measurement of magnetic susceptibility anisotropy (magnetic fabric) of marine sediment samples showing this effect (Hailwood et al., 1989) indicates that the long axes of the magnetic grains are preferentially aligned along the push axis and that this property is not restricted to the surface layers of the sample, but instead penetrates deep into its interior.

The reason why, in the present study, this effect is present in the APC cores but not in the XCB cores of Site 704 appears to relate to the greater mechanical strength of the latter cores and consequently the greater resistance to realignment of 

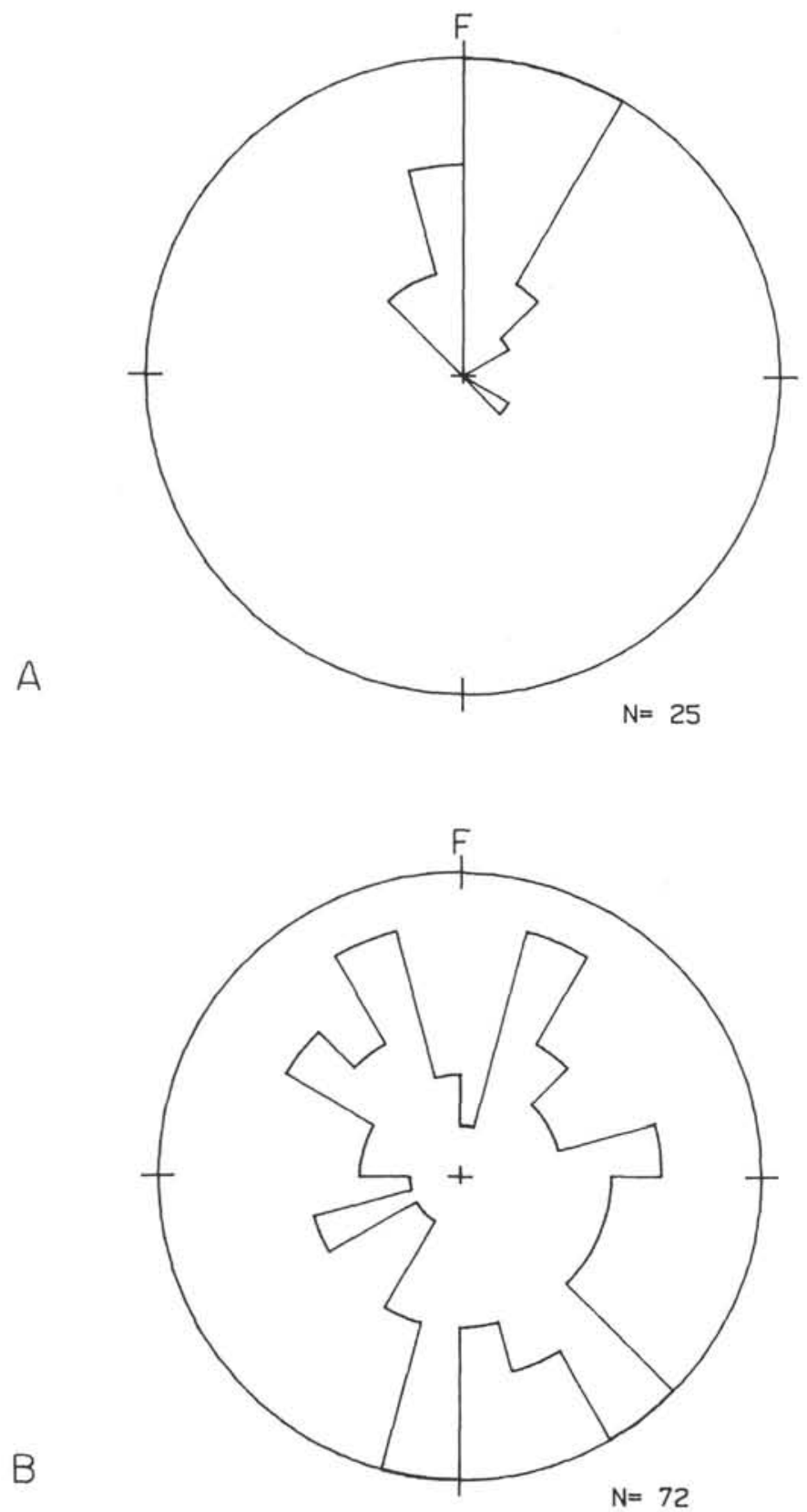

Figure 9. Circular histogram showing the distribution of paleomagnetic declination values for discrete samples from Hole 704B. The reference azimuth, $F$, is perpendicular to the split face of the core (see Fig. 7). A. Samples from APC cores. B. Samples from XCB cores.

magnetic mineral grains during subsampling. As noted in the "Magnetic Intensity" section, the sediments in the upper 100 $\mathrm{m}$ or so at this site are particularly soft and water-saturated and thus are likely to be prone to sampling deformation of this kind. The stiffer sediments cored with the APC system at Site 703 do not appear to show the effect.

Although this "sample push" effect has modified the relatively weak horizontal component of magnetization, there is no evidence that the much stronger vertical component (which is orthogonal to the push axis) has been significantly affected. Because the polarity of the stable characteristic magnetization is deduced solely from the vertical component, there is no reason to doubt the validity of the polarity determinations from these samples.

\section{MAGNETIC POLARITIES}

The magnetic inclination values determined from the shipboard WCC measurements and from the post-cruise DSC measurements are shown for Holes 703A, 704A, and 704B in Figures 10, 11, and 12 , respectively. The magnetic polarity record inferred from these inclination values is shown on the black-and-white bar charts adjacent to the inclination plots. In general, the magnetic inclination values display a series of regular changes from steep positive values to steep negative values, defining a clear succession of polarity reversals. Within the intervals of dominantly normal or reverse polarity, however, are fluctuations in inclination values, some of which involve a change of sign (e.g., at 57.3 and 63.5 mbsf in Hole $703 \mathrm{~A})$. In such cases it is necessary to decide whether these intervals represent true periods of opposite polarity, shorter period magnetic "excursions," or large-amplitude features of the geomagnetic secular variation or are attributable to experimental factors, such as sampling disturbance or accidental inversion of discrete samples. The criterion adopted in the present study is the same as that used by Hailwood and Clement (this volume) for the Site 699 and 700 paleomagnetic records in which short intervals of opposite inclination values are accepted as representing "true" magnetic polarity zones and are incorporated into the polarity logs of Figures 10 through 12 if they are defined by more than one adjacent or closely associated inclination determination (either whole-core or discrete sample) in excess of $40^{\circ}$. Where they are defined by a single (reliable) inclination value above this limit or more than one inclination value below the limit and extending over $>0.5 \mathrm{~m}$ of section, they may be included in the polarity log, but are marked with a query.

\section{Hole 703A}

The magnetic inclination records and polarity logs for Hole 703A are shown in Figure 10. Over much of the interval for which paleomagnetic data are available for this hole the WCC magnetic inclination values are close to the expected value for this latitude based on the axial geocentric dipole model $\left(65^{\circ}\right)$. However, significant intervals of anomalously low WCC inclination values occur in the intervals 44-53 and 92-115 mbsf. The DSC inclination values in these intervals are generally close to the expected value, suggesting that the WCC values may be erroneous. As with the East Georgia Basin Sites 699 and 700 (Hailwood and Clement, this volume) the anomalously shallow inclination values occur more commonly in reverse polarity intervals than in normal polarity ones. This may reflect either the incomplete removal of a normal polarity overprint of the main body of the sediment core or, alternatively, the presence of a normal polarity magnetization in the settled drilling slurry between the core and the liner. Because both the WCC inclination values and the majority of the DSC inclination values are based on partial demagnetization in similar alternating fields (generally $10 \mathrm{mT}$ ), the absence of the inclination errors in the DSC records suggests that the latter explanation is more likely to be applicable.

The combination of WCC and DSC data provides a more or less continuous magnetostratigraphic record for the depth interval from 15 to $115 \mathrm{mbsf}$ at Hole $703 \mathrm{~A}$. Unfortunately, because of intervals of extensive drilling disturbance, such as in Core 114-703A-14H (118.9-128.4 mbsf), and poor recovery beneath this, little useful paleomagnetic data were obtained from beneath 115 mbsf.

\section{Hole 704A}

Because of the very soft, water-saturated nature of the upper $150-\mathrm{m}$ section of sediment at Site 704, WCC paleomagnetic determinations were not attempted on the APC cores 
Inclination (degrees)

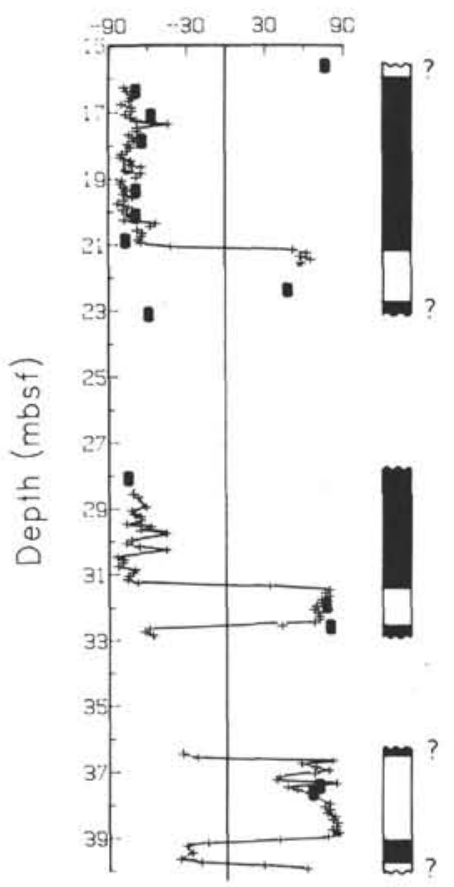

Inclination (degrees)

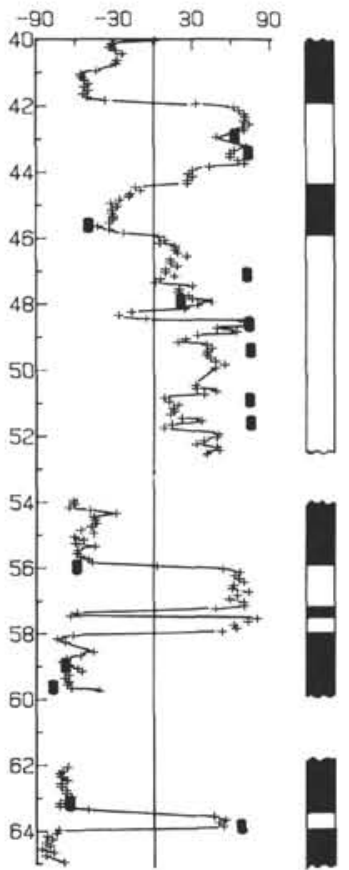

Figure 10. Variation of inclination of stable remanent magnetization and inferred polarity with depth in Hole 703A. Crosses indicate inclination determinations made on the shipboard whole-core magnetometer system after AF demagnetization at either 5 or $9 \mathrm{mT}$. Solid symbols represent directions determined from incremental AF demagnetization analyses of discrete samples using the Southampton University cryogenic magnetometer system. In the polarity column black indicates normal polarity and white reverse polarity. See the text for discussion of the criteria used for defining the polarity log from observed inclination data.

(with the exception of Core 114-704A-16H). For this reason the magnetostratigraphy of this interval, which has provided important late Pliocene and Pleistocene paleoclimatic and paleoceanographic information, was defined from discrete sample paleomagnetic determinations alone. A significant gap occurs in the Hole 704A paleomagnetic data set for the depth interval of 24-44 mbsf (Fig. 11), but this is bridged by data for this interval in Hole 704B (Fig. 12). In general, the magnetic inclination values for this depth interval are significantly shallower than the expected value of $65^{\circ}$. This may represent a combination of the effects of mild drilling disturbance and poor definition of the magnetic vectors because of the very weak magnetic intensities. Scattered short polarity intervals based on single sample determinations are observed (e.g., at about 1.9, 14.1, and $71.2 \mathrm{mbsf}$ ). However, the reliability of these is very doubtful and they have not been included in the final magnetostratigraphic log (Fig. 14).

The WCC inclination record for the depth interval from 140 to $168 \mathrm{mbsf}$ is very noisy and does not agree in several places with DSC determinations (e.g., at 144.6 and between 150.9 and 152.4 mbsf; Fig. 11). However, below 168 mbsf there is generally good correspondence between the two data sets.

\section{Hole 704B}

As for Hole 704A, the discrete sample paleomagnetic data for the APC cores are noisy, but in general the polarity determinations from these samples are considered reliable.
Inclination (degrees)
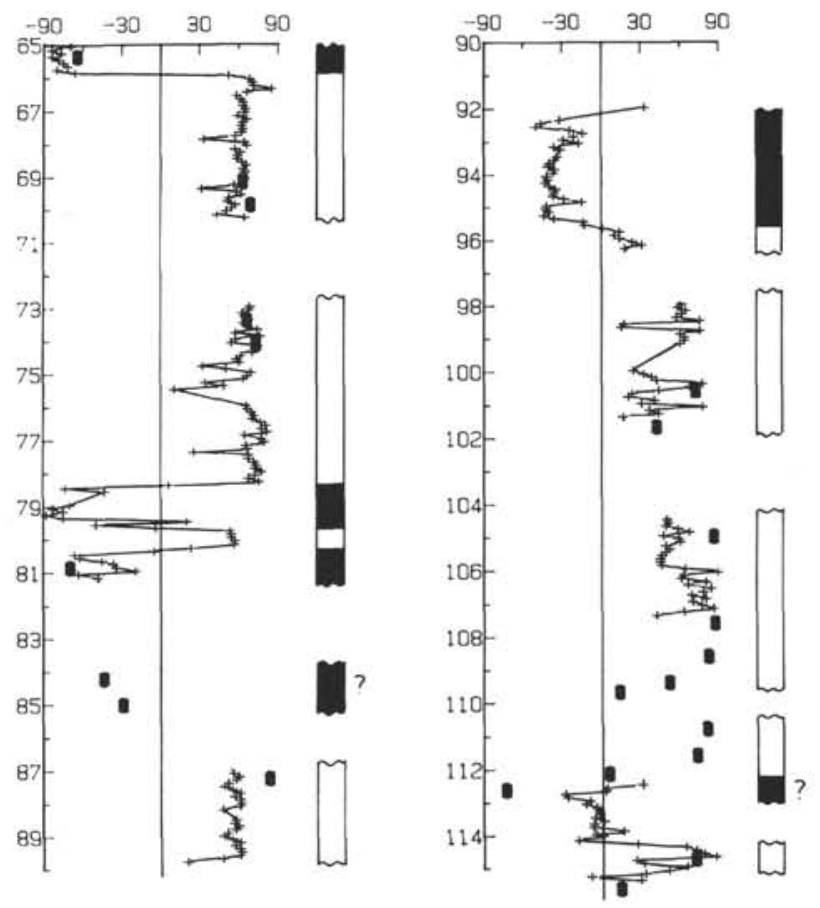

Figure 10 (continued).

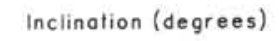

Inclinotion (degrees)
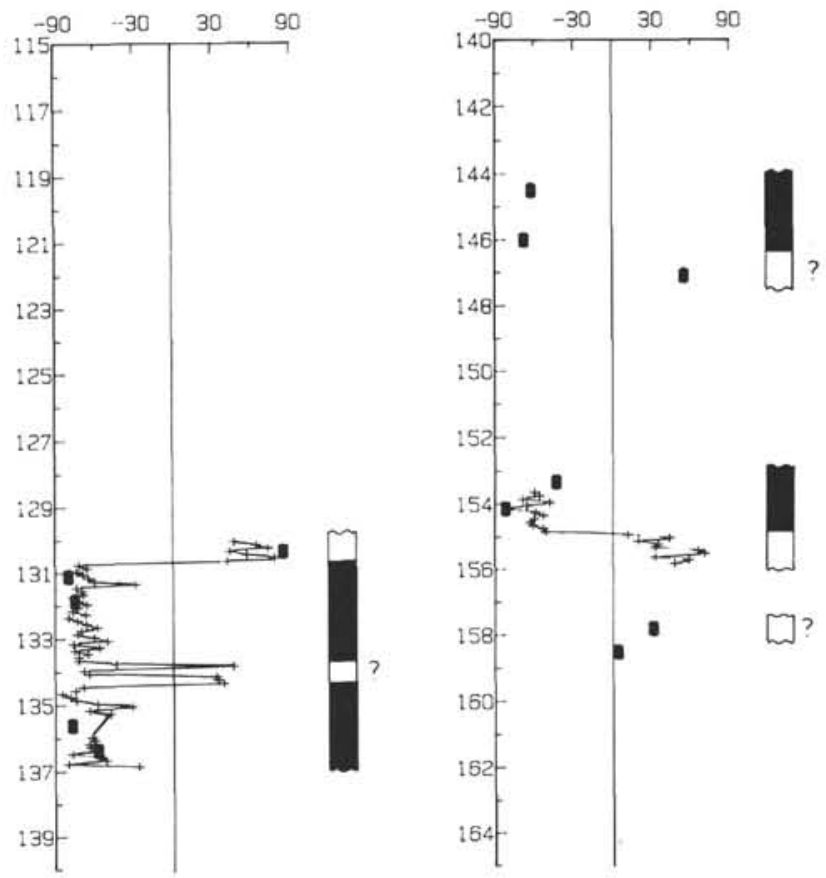

Figure 10 (continued).

Only short intervals of WCC data are available for the XCB cores in the interval from 150 to 210 mbsf, but these data show general agreement with the DSC data (Fig. 12).

Below 210 mbsf there is a significant improvement in the quality and continuity of both the WCC and the DSC data (Fig. 12). The combined data set provides good definition of 


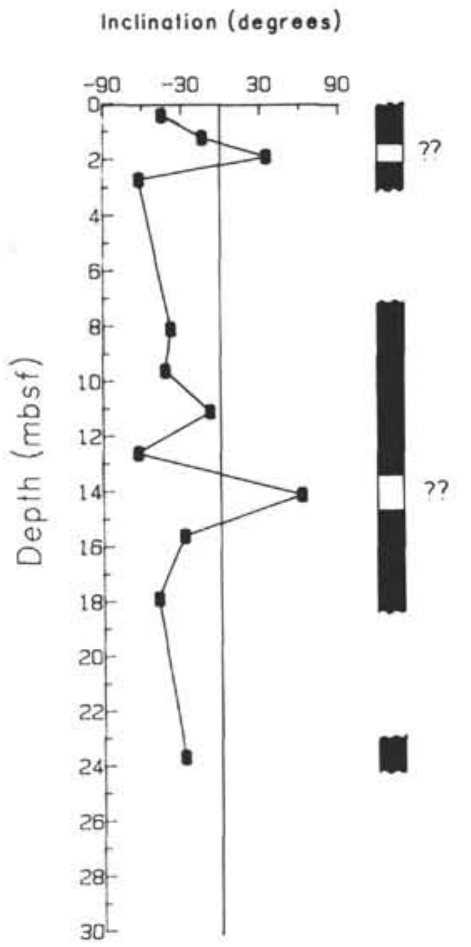

Inclination (degrees)

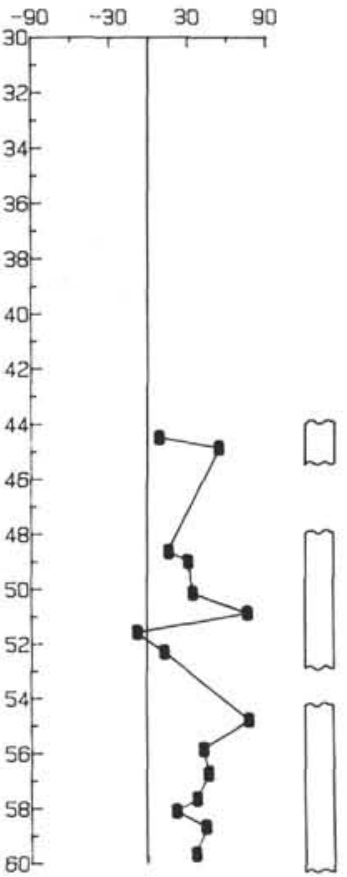

Figure 11. Variation of inclination of stable remanent magnetization and inferred magnetic polarity with depth in Hole 704A. Symbols and conventions as in Figure 10.
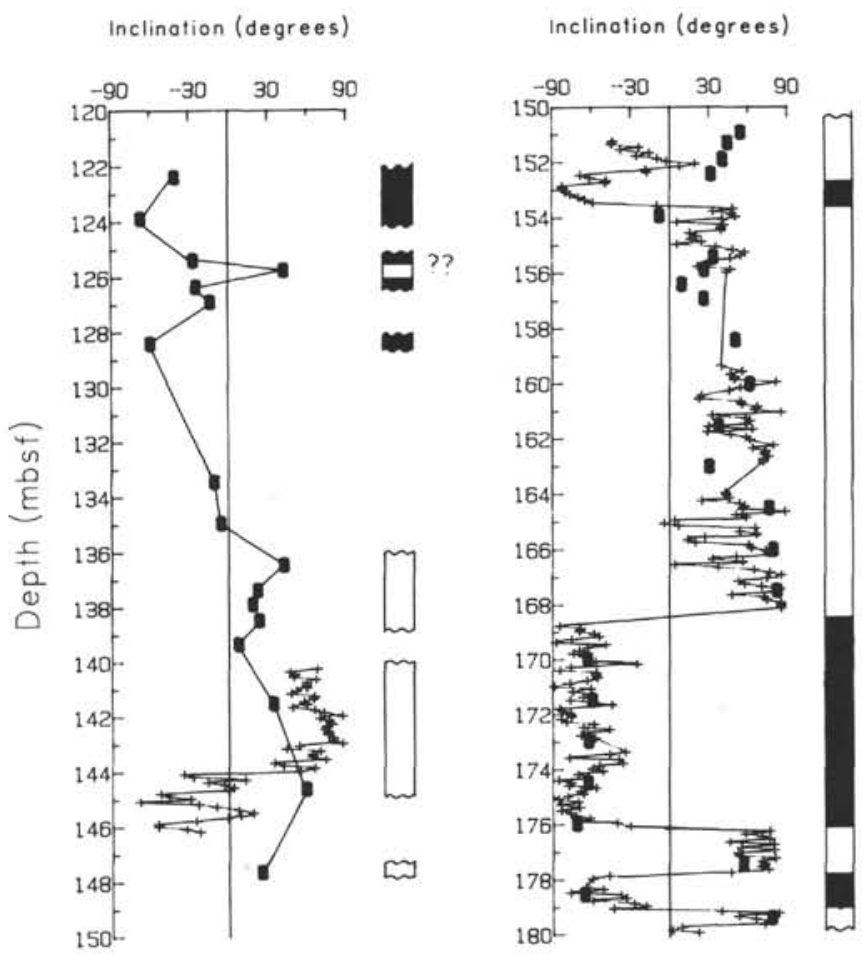

Figure 11 (continued).
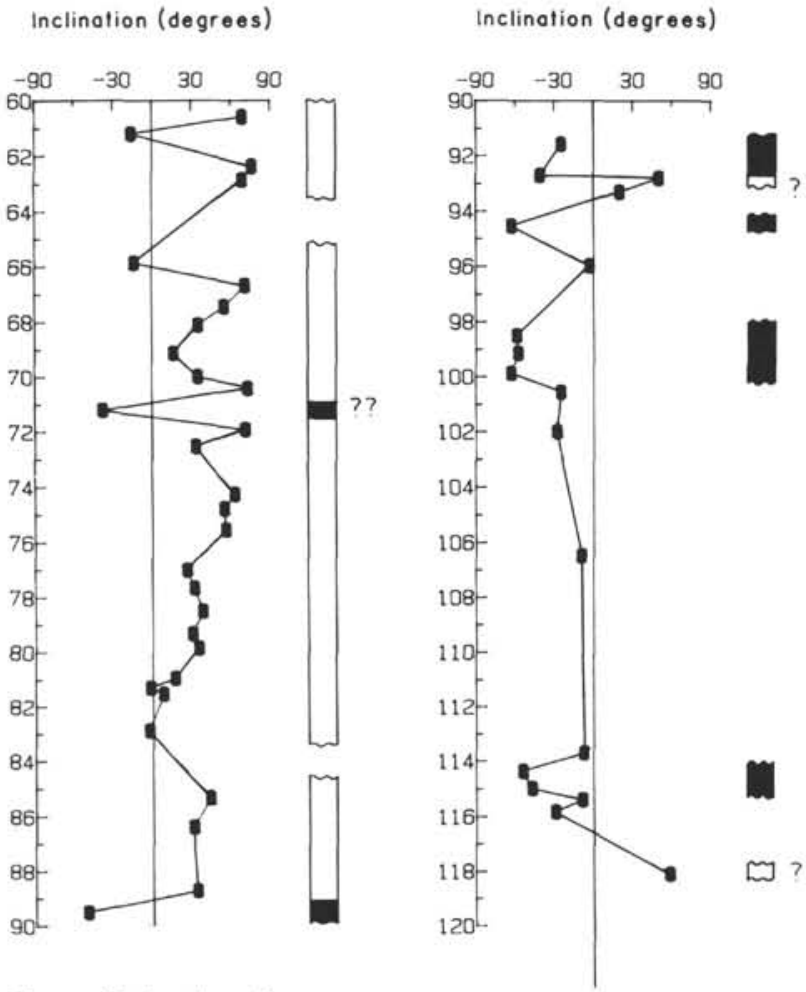

Figure 11 (continued).

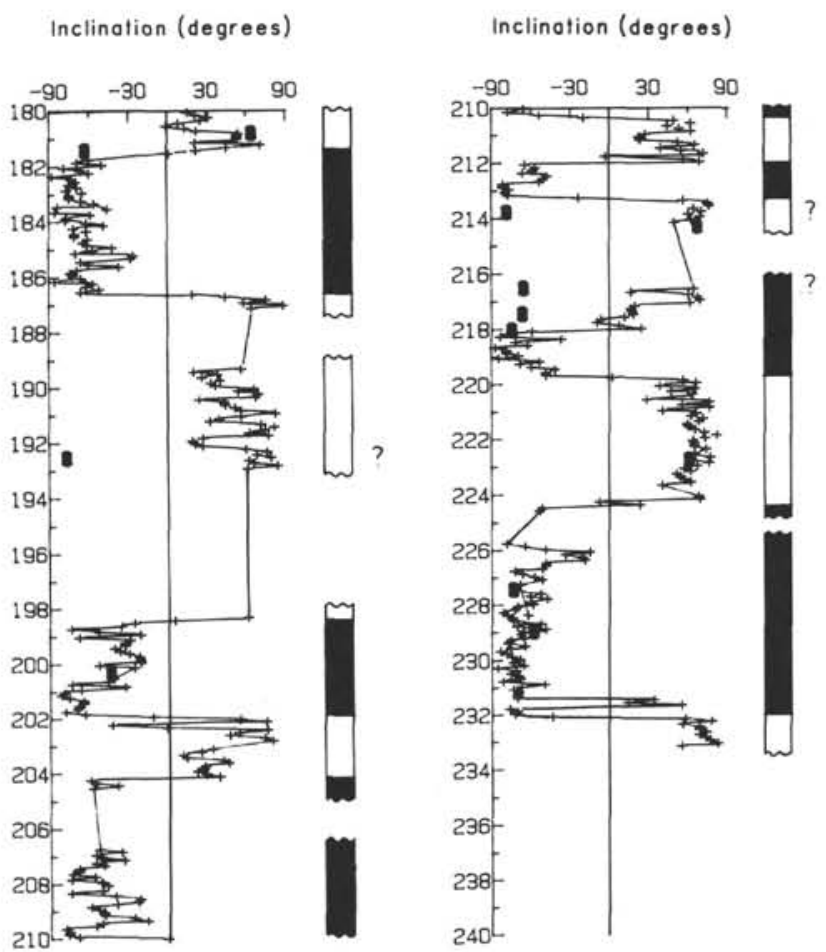

Figure 11 (continued). 

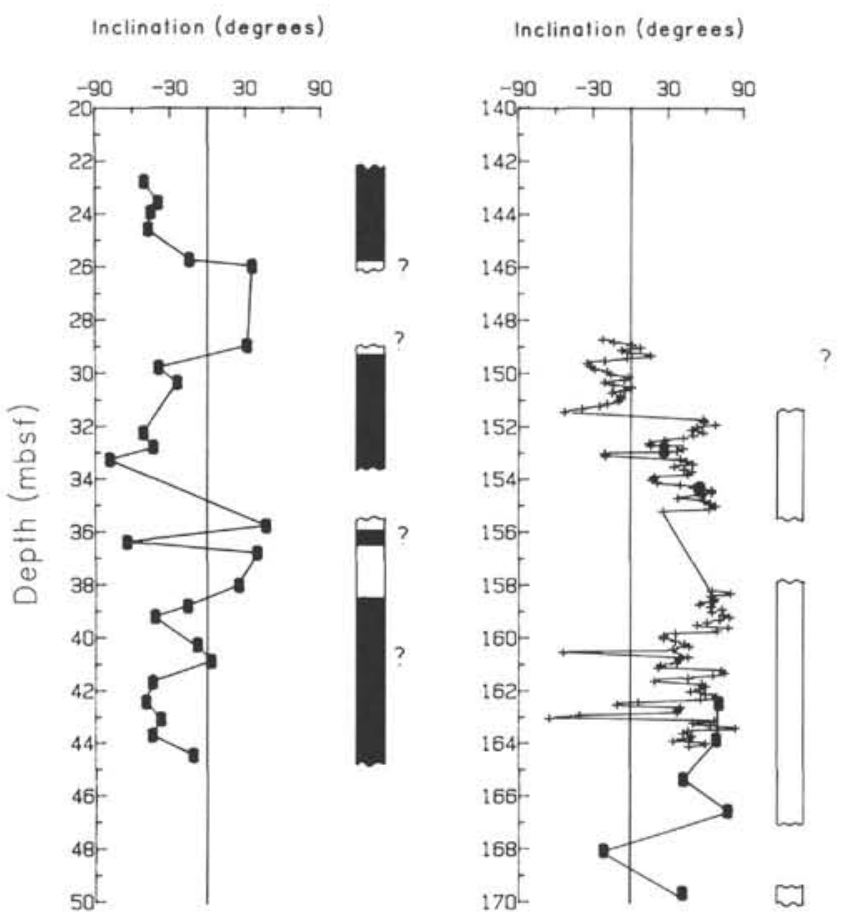

Figure 12. Variation of inclination of stable remanent magnetization and inferred magnetic polarity with depth in Hole 704B. Symbols and conventions as in Figure 10.
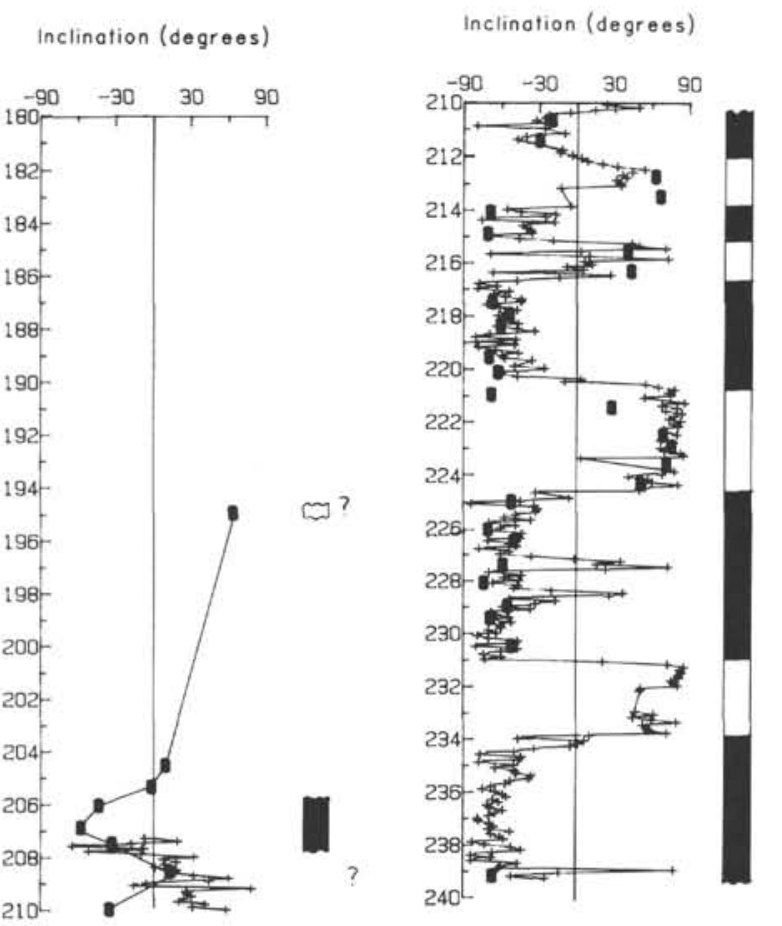

Figure 12 (continued).

the sequence of normal and reverse polarity magnetozones over much of the interval from 210 to 342 mbsf, beneath which the record becomes more discontinuous. As with Holes 703A and $704 \mathrm{~A}$, there are intervals of anomalously shallow or variable WCC inclination values (e.g., 262-270 and 280-290 mbsf). In many cases the corresponding DSC inclination values show more internal consistency (e.g., in the interval

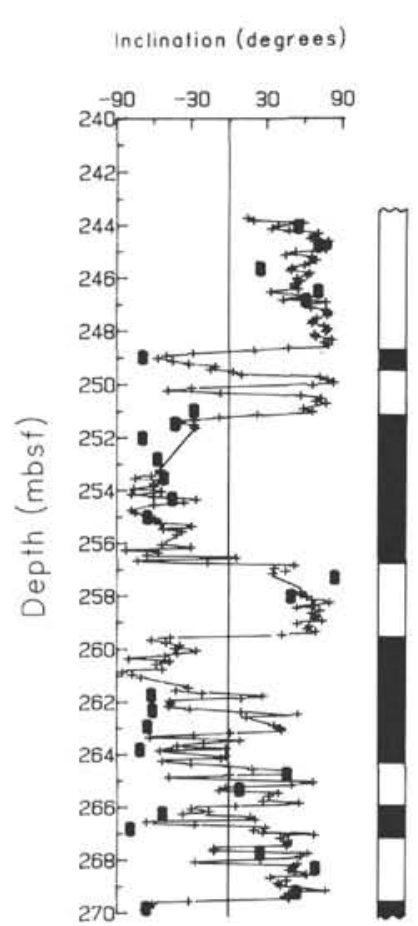

Inclination (degrees)

Figure 12 (continued).

$$
\text { Inclination (degrees) }
$$

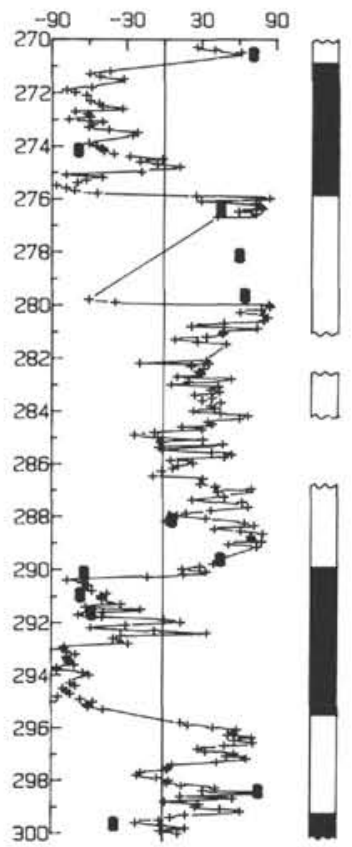

Inclination (degrees)

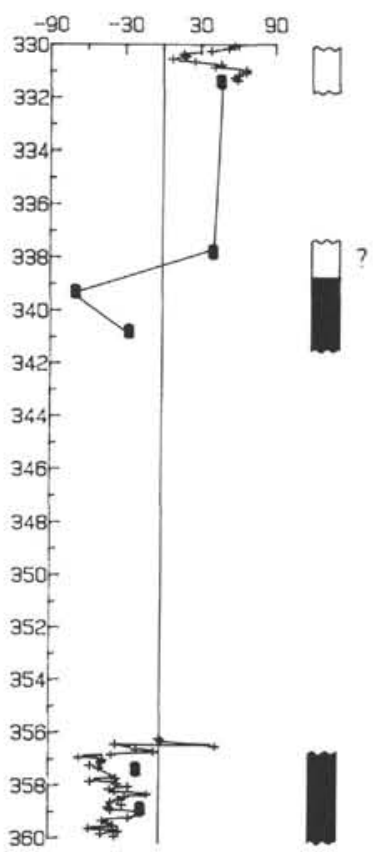

Figure 12 (continued).

261.7-263.8 mbsf), but in other cases (e.g., 264.7-270 and $360-390$ mbsf) they also show a high variability. This is most likely due to drilling disturbance. For some intervals (e.g., $370.5-375.5 \mathrm{mbsf}$ ) the variability is too high to permit even tentative polarity assignments to be made, but in other cases, where the variability is large but not excessive and the WCC and DSC data show internal consistency (e.g., 376-390 mbsf), provisional polarity assignments were made. 

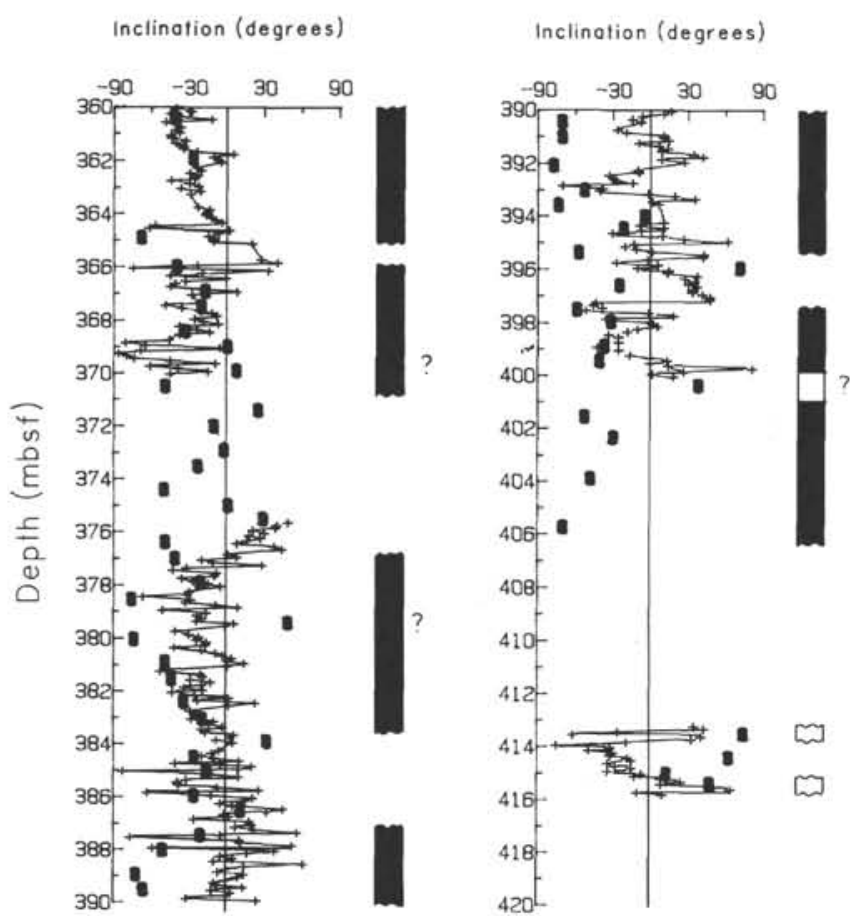

Figure 12 (continued).

Inclination (degrees)

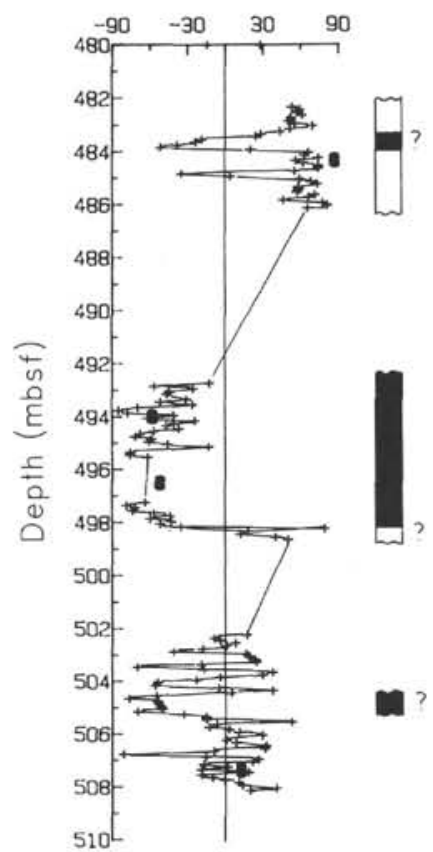

Figure 12 (continued).
Inclination (degrees)

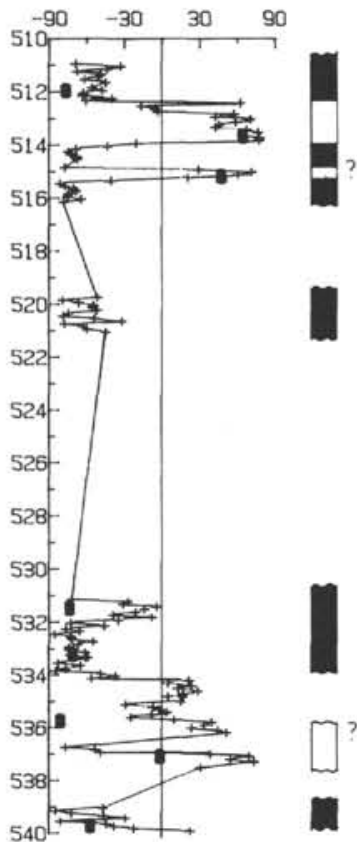

Inclination (degrees)

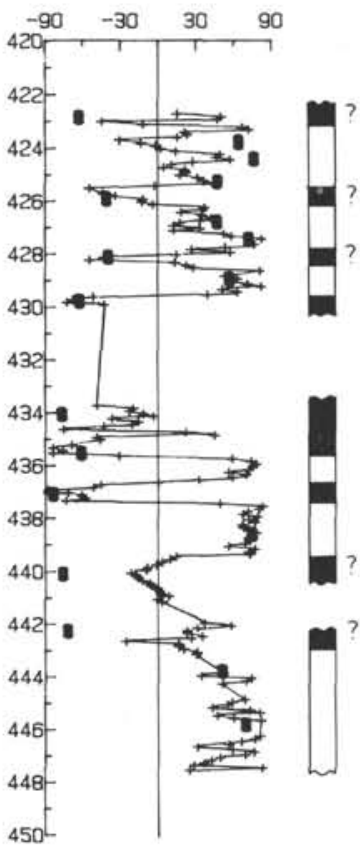

Inclination (degrees)

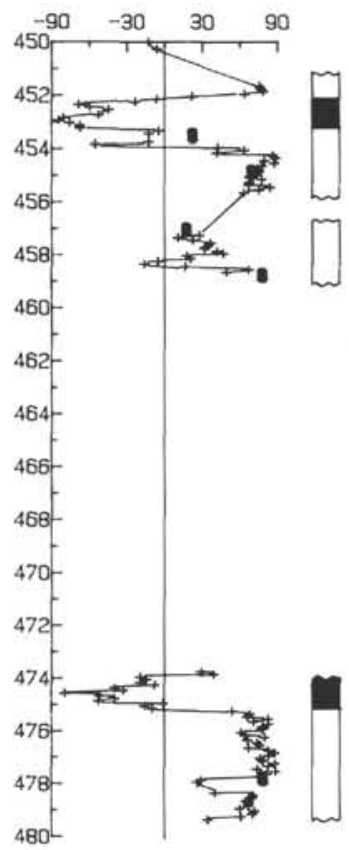

Figure 12 (continued).

The magnetostratigraphic records for Holes 704A and 704B overlap in the interval from 210 to 233 mbsf (Figs. 11 and 12). The quality of the data for Hole 704B is relatively poor in the upper part of this interval and consequently the correspondence between the polarity sequences for the two holes is not good above $220 \mathrm{mbsf}$. However, below this depth the quality of the data for both holes is good and the correspondence between the two data sets is excellent. The paleomagnetic

Inclinotion (degrees)

Inclination (degrees)
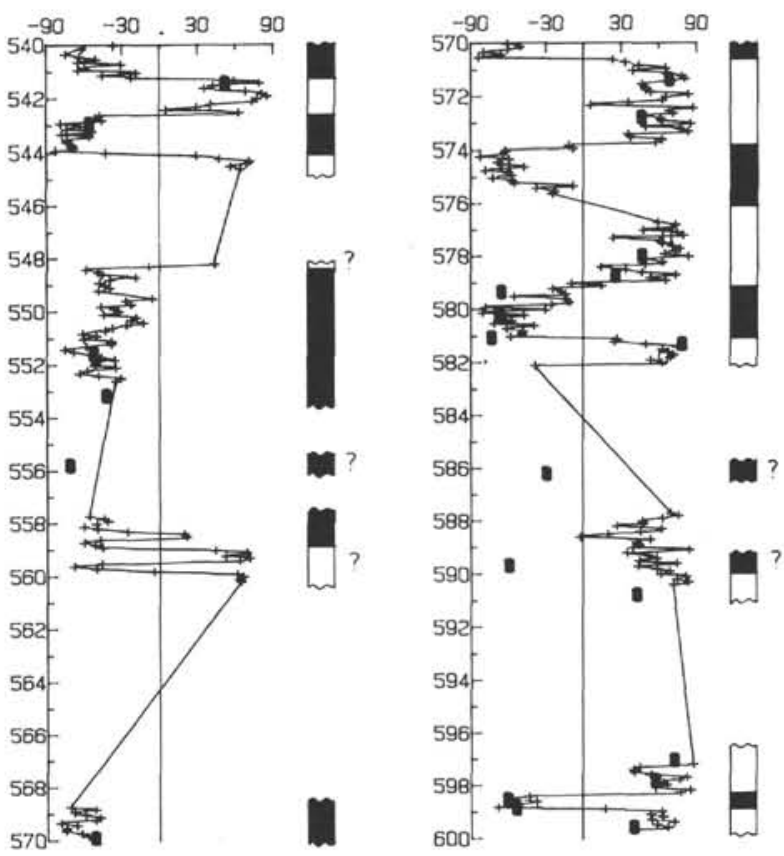

Figure 12 (continued).

data from the two holes were spliced together at this depth. Thus, in the composite record (Fig. 14) the data for above 220 mbsf are from Hole 704A, with the exception of the data gap in the interval from 22 to 45 mbsf in this hole, which is bridged by data from Hole 704B. The data from below $220 \mathrm{mbsf}$ are from Hole 704B. The depths of the principal polarity transitions at the two sites are listed in Table 2. 
Inclination (degrees)

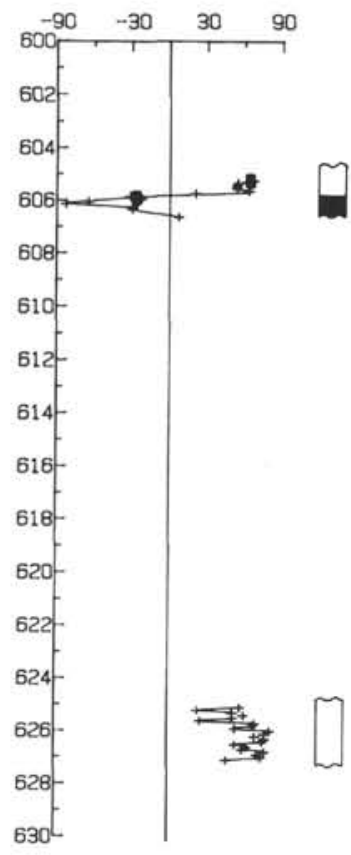

Figure 12 (continued).

\section{MAGNETIC STRATIGRAPHY}

\section{Site $\mathbf{7 0 3}$}

The sequence of magnetic polarity zones defined for Hole $703 \mathrm{~A}$ is plotted against the GPTS of Berggren et al. (1985) in Figure 13, together with available age-calibrated biostratigraphic datums. The latter datums indicate that the observed magnetic polarity sequence extends from the middle Eocene to the early Miocene, with significant hiatuses present within the late Oligocene.

The top of the Reticulofenestra bisecta nannofossil Zone has been identified in Core 114-703 A-5H, in the depth interval from 35.11 to $42.90 \mathrm{mbsf}$ (Crux, this volume). This datum has been correlated with the Oligocene/Miocene boundary by Wise (1983) and Berggren et al. (1985), but J. Backman (pers. comm., 1988) has suggested that it may be significantly older. In Hole 699A this datum occurs within a long reverse polarity interval that has been correlated with Chron C6CR by Hailwood and Clement (this volume). However, in Hole 703A it was placed within an interval of alternating reverse and normal polarity (Fig. 13). This may possibly be explained by reworking of this species in Hole $703 \mathrm{~A}$ or its premature disappearance in Hole 699A due to environmental factors. The only long interval of reverse polarity in this part of the Hole 703A sequence that might correspond with Chron C6CR lies in the interval from 46 to 53 mbsf. On the basis of this correlation the sequence of normal and reverse polarity magnetozones from 28 to 46 mbsf can be assigned to Chron C6BN to $\mathrm{C} 6 \mathrm{CN}$. This interpretation supports the positioning of the top $R$. bisecta datum at the Oligocene/Miocene boundary.

Interpretation of the set of magnetozones at $46-53 \mathrm{mbsf}$ is difficult because of the stratigraphic hiatuses within this interval. However, identification of the P20/21 foraminifer zonal boundary at 81 mbsf (Nocchi et al., this volume) allows the long reverse polarity magnetozone at $66-78.5 \mathrm{mbsf}$ to be correlated with confidence to Chron C10R and the underlying $\mathrm{N}-\mathrm{R}-\mathrm{N}$ sequence in the interval from 78.5 to $95.5 \mathrm{mbsf}$ with
Table 2. Depth of polarity transitions, Sites 703 and 704.

\begin{tabular}{|c|c|c|c|}
\hline $\begin{array}{l}\text { Depth range } \\
\text { (mbsf) }\end{array}$ & $\begin{array}{l}\text { Change in polarity } \\
\text { with depth }\end{array}$ & $\begin{array}{c}\text { Depth range } \\
\text { (mbsf) }\end{array}$ & $\begin{array}{l}\text { Change in polarity } \\
\text { with depth }\end{array}$ \\
\hline \multicolumn{2}{|l|}{ Hole 703A } & \multicolumn{2}{|l|}{ Hole 704B } \\
\hline $15.97 \pm 0.37$ & $\mathrm{R}-\mathrm{N}$ & $224.76 \pm 0.21$ & $\mathrm{R}-\mathrm{N}$ \\
\hline $21.10 \pm 0.05$ & N-R & $231.05 \pm 0.10$ & N-R \\
\hline $22.72 \pm 0.37$ & $\mathrm{R}-\mathrm{N}$ & $233.85 \pm 0.10$ & $\mathrm{R}-\mathrm{N}$ \\
\hline $31.35 \pm 0.10$ & N-R & $241.62 \pm 2.48$ & N-R \\
\hline $32.59 \pm 0.05$ & $\mathrm{R}-\mathrm{N}$ & $248.80 \pm 0.15$ & $\mathrm{R}-\mathrm{N}$ \\
\hline $36.54 \pm 0.09(?)$ & N-R & $249.45 \pm 0.30$ & N-R \\
\hline $39.14 \pm 0.10$ & $\mathrm{R}-\mathrm{N}$ & $251.25 \pm 0.20$ & $\mathrm{R}-\mathrm{N}$ \\
\hline $39.79 \pm 0.15$ & N-R & $256.75 \pm 0.10$ & $\mathrm{~N}-\mathrm{R}$ \\
\hline $40.00 \pm 0.10$ & $\mathrm{R}-\mathrm{N}$ & $259.50 \pm 0.05$ & R-N \\
\hline $41.89 \pm 0.05$ & N-R & $264.29 \pm 0.45$ & $\mathrm{~N}-\mathrm{R}$ \\
\hline $44.54 \pm 0.40$ & $\mathrm{R}-\mathrm{N}$ & $265.79 \pm 0.45$ & R-N \\
\hline $45.99 \pm 0.25$ & N-R & $267.29 \pm 0.45$ & $\mathrm{~N}-\mathrm{R}$ \\
\hline $53.24 \pm 0.70$ & $\mathrm{R}-\mathrm{N}$ & $269.55 \pm 0.10$ & $\mathrm{R}-\mathrm{N}$ \\
\hline $55.99 \pm 0.04$ & N-R & $270.10 \pm 0.25$ & N-R \\
\hline $57.29 \pm 0.05$ & $\mathrm{R}-\mathrm{N}$ & $270.82 \pm 0.32$ & $\mathrm{R}-\mathrm{N}$ \\
\hline $57.49 \pm 0.05$ & N-R & $275.85 \pm 0.10$ & N-R \\
\hline $57.99 \pm 0.05$ & $\mathrm{R}-\mathrm{N}$ & $290.06 \pm 0.01$ & $\mathrm{R}-\mathrm{N}$ \\
\hline $63.44 \pm 0.10$ & N-R & $295.60 \pm 0.35$ & N-R \\
\hline $63.89 \pm 0.04$ & $\mathrm{R}-\mathrm{N}$ & $299.37 \pm 0.22$ & $\mathrm{R}-\mathrm{N}$ \\
\hline $65.89 \pm 0.05$ & N-R & $306.15 \pm 0.10$ & N-R \\
\hline $78.34 \pm 0.10$ & $\mathrm{R}-\mathrm{N}$ & $309.10 \pm 0.25$ & $\mathrm{R}-\mathrm{N}$ \\
\hline $79.84 \pm 0.10$ & N-R & $318.55 \pm 0.10$ & N-R \\
\hline $80.29 \pm 0.15$ & R-N & $324.10 \pm 0.15$ & $\mathrm{R}-\mathrm{N}$ \\
\hline $86.02 \pm 1.02$ & N-R & $327.05 \pm 0.15$ & N-R \\
\hline $90.99 \pm 1.35$ & $\mathrm{R}-\mathrm{N}$ & $338.55 \pm 0.75$ & $\mathrm{R}-\mathrm{N}$ \\
\hline $95.74 \pm 0.40$ & N-R & $409.64 \pm 3.91$ & N-R \\
\hline $112.09 \pm 0.51(?)$ & $\mathrm{R}-\mathrm{N}$ & $429.60 \pm 0.05$ & $\mathrm{R}-\mathrm{N}$ \\
\hline $113.47 \pm 0.86(?)$ & N-R & $435.65 \pm 0.10$ & N-R \\
\hline $130.70 \pm 0.05$ & $\mathrm{R}-\mathrm{N}$ & $436.60 \pm 0.15$ & $\mathrm{R}-\mathrm{N}$ \\
\hline $133.80 \pm 0.05$ & N-R & $437.40 \pm 0.05$ & N-R \\
\hline $134.40 \pm 0.05$ & $\mathrm{R}-\mathrm{N}$ & $439.72 \pm 0.37$ & R-N \\
\hline $146.55 \pm 0.55$ & N-R & $443.00 \pm 0.75$ & N-R \\
\hline \multirow[t]{2}{*}{$154.95 \pm 0.10$} & \multirow[t]{2}{*}{$\mathrm{N}-\mathrm{R}$} & $452.15 \pm 0.20$ & $\mathrm{R}-\mathrm{N}$ \\
\hline & & $453.60 \pm 0.35$ & N-R \\
\hline \multicolumn{2}{|l|}{ Hole 704B } & $475.05 \pm 0.20$ & N-R \\
\hline \multirow{4}{*}{$\begin{array}{l}34.51 \pm 1.25 \\
38.41 \pm 0.39 \\
44.27 \pm 0.57\end{array}$} & N-R & $489.50 \pm 3.35$ & $\mathrm{R}-\mathrm{N}$ \\
\hline & $\mathrm{R}-\mathrm{N}$ & $498.20 \pm 0.05$ & N-R \\
\hline & $\mathrm{N}-\mathrm{R}$ & $512.59 \pm 0.25$ & $\mathrm{~N}-\mathrm{R}$ \\
\hline & & $513.94 \pm 0.10$ & $\mathrm{R}-\mathrm{N}$ \\
\hline \multirow{2}{*}{\multicolumn{2}{|c|}{ Hole 704A }} & $535.79 \pm 0.05$ & N-R \\
\hline $44.27 \pm 0.57$ & & $538.24 \pm 0.80$ & $\mathrm{R}-\mathrm{N}$ \\
\hline & N-R & $541.24 \pm 0.10$ & N-R \\
\hline $\begin{array}{l}89.09 \pm 0.40 \\
168.4 \pm 0.30\end{array}$ & $\mathrm{R}-\mathrm{N}$ & $542.59 \pm 0.05$ & $\mathrm{R}-\mathrm{N}$ \\
\hline $168.4 \pm 0.30$ & $\mathrm{R}-\mathrm{N}$ & $544.14 \pm 0.10$ & N-R \\
\hline $176.10 \pm 0.15$ & N-R & $548.34 \pm 0.09(?)$ & R-N \\
\hline $177.80 \pm 0.05$ & $\mathrm{R}-\mathrm{N}$ & $558.99 \pm 0.05$ & N-R \\
\hline $179.10 \pm 0.05$ & N-R & $564.49 \pm 4.25$ & $\mathrm{R}-\mathrm{N}$ \\
\hline $181.50 \pm 0.15$ & $\mathrm{R}-\mathrm{N}$ & $570.69 \pm 0.15$ & $\mathrm{~N}-\mathrm{R}$ \\
\hline $186.65 \pm 0.10$ & N-R & $573.89 \pm 0.15$ & $\mathrm{R}-\mathrm{N}$ \\
\hline $198.55 \pm 0.20$ & $\mathrm{R}-\mathrm{N}$ & $576.09 \pm 0.65$ & N-R \\
\hline $201.95 \pm 0.10$ & $\mathrm{~N}-\mathrm{R}$ & $579.14 \pm 0.20$ & $\mathrm{R}-\mathrm{N}$ \\
\hline $204.20 \pm 0.05$ & R-N & $581.19 \pm 0.13$ & N-R \\
\hline $210.35 \pm 0.10$ & N-R & $590.24 \pm 0.55$ & $\mathrm{~N}-\mathrm{R}$ \\
\hline $212.00 \pm 0.05$ & $\mathrm{R}-\mathrm{N}$ & $598.39 \pm 0.05$ & $\mathrm{R}-\mathrm{N}$ \\
\hline $213.25 \pm 0.10$ & N-R & $598.94 \pm 0.10$ & $\mathrm{~N}-\mathrm{R}$ \\
\hline $215.40 \pm 1.11$ & $\mathrm{R}-\mathrm{N}$ & $605.74 \pm 0.10$ & $\mathrm{R}-\mathrm{N}$ \\
\hline $219.75 \pm 0.10$ & N-R & & \\
\hline
\end{tabular}

Note: Transitions interpolated within coring or sampling gaps can be identified from the associated large range of uncertainty. Boundaries of thin or otherwise poorly defined polarity intervals are indicated by a query.

Chrons $\mathrm{C} 11 \mathrm{~N}$ to $\mathrm{C} 12 \mathrm{~N}$ (although minor hiatuses may be present within this sequence).

The set of nannofossil and foraminifer datums in the interval from 100 to 140 mbsf indicates that the distinctive long reverse magnetozone in the interval 95.5 to $\sim 112$ mbsf should represent Chron $\mathrm{C} 12 \mathrm{R}$. Unfortunately the absence of paleomagnetic data for the interval from 115 to 130 mbsf prevents the recognition of a record of Chrons C13N and C13R, but it seems likely that the normal magnetozone in the interval from 130.5 to 137 mbsf represents Chron C15N. The correlation line through the $\mathrm{C} 15 \mathrm{~N} / \mathrm{C} 13 \mathrm{R}$ boundary and the available biostrati- 


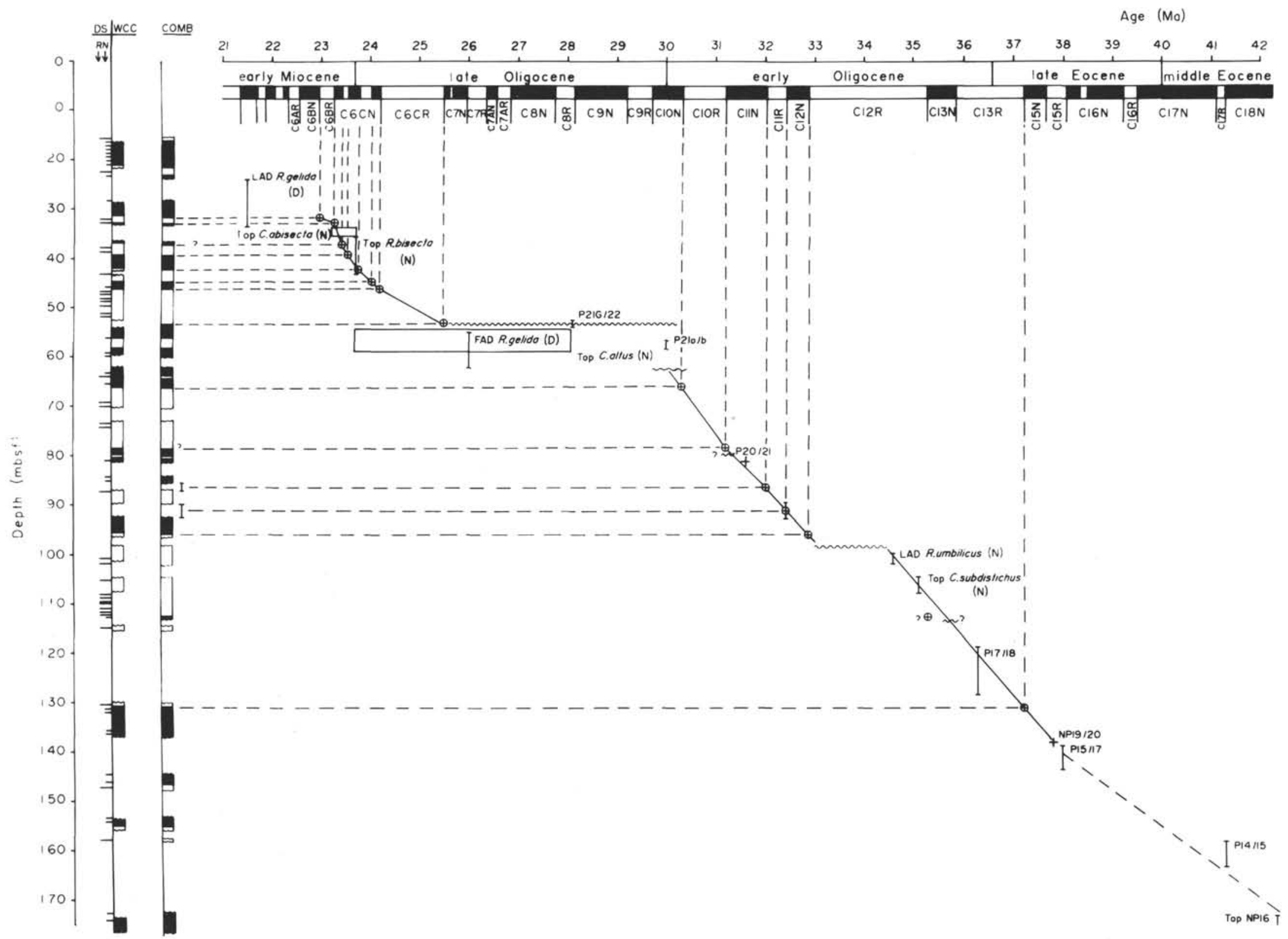

Figure 13. Correlation of the magnetic polarity reversal record for Hole 703A with the GPTS of Berggren et al. (1985). The key biostratigraphic datums used to constrain this correlation are shown. $\mathrm{FAD}=$ first-appearance datum; $\mathrm{LAD}=$ last-appearance datum. 
graphic datums is not concordant with that for Chrons $\mathrm{C} 12 \mathrm{~N}$ to $\mathrm{C} 10 \mathrm{~N}$. It is concluded that a hiatus may be present at a depth of about $98 \mathrm{mbsf}$.

\section{Site 704}

The magnetic polarity sequence derived from the combined paleomagnetic records of Holes 704A and 704B is plotted against the Neogene GPTS of Berggren et al. (1985) in Figure 14. All of the plotted available biostratigraphic datums defined for these two holes at the time of writing are listed in Table 3. These datums are discussed in more detail in the associated paper by Müller et al. (this volume).

The dominantly normal polarity magnetozone in the upper few tens of meters of both holes clearly represents the Brunhes Chron. However, there is a small element of uncertainty in the positioning of the base of this magnetozone. Reverse polarity magnetizations were observed in two isolated samples at depths of 25.99 and 28.97 mbsf, respectively, in Hole 704B (Fig. 12). However, because of the relatively large sampling gap between these samples, it is unclear whether or not they represent a reverse polarity interval of significant duration. Three closely associated reverse polarity determinations in the depth interval 35.77 38.02 mbsf do appear to represent a significant reverse polarity interval. Consequently, the base of the Brunhes Chron is placed at the top of this short reverse polarity interval (at $34.51 \pm 1.25 \mathrm{mbsf}$ ). The underlying short normal polarity interval (38.41-44.27 mbsf) then can be correlated with the Jaramillo Subchron. It should be noted that the lower Jaramillo boundary is bracketed between the base of the normal polarity interval in Hole 704B (43.7 mbsf; Fig. 12) and the top of the reverse polarity interval in Hole $704 \mathrm{~A}$ (44.85 mbsf; Fig. 11).

The underlying long reverse polarity interval can be correlated confidently with the late Matuyama Chron, and the young end of the Olduvai Subchron is identified at $89.09 \mathrm{mbsf}$. Because of a sampling gap between 100 and 114 mbsf the older boundary of this subchron is not defined, but a set of short normal polarity intervals in the interval from 114 to 129 mbsf may represent the Rúnion Subchrons.

The Matuyama/Gauss Chron boundary is clearly defined at $168.45 \mathrm{mbsf}$ and the Gauss/Gilbert Chron boundary at 186.65 mbsf. Beneath this level the correspondence between the observed sequence of magnetozones and the GPTS is not as good. The set of four distinct normal polarity zones in the depth interval 200-220 mbsf can be correlated with the four Gilbert normal polarity subchrons. However, these normal zones appear to be anomalously long, and the underlying reverse interval, correlated with the early part of the Gilbert Chron, is somewhat short. However, these small discrepancies can be explained by short-term fluctuations in the sediment-accumulation rate.

The N-R-N polarity sequence in the interval $225-240$ mbsf shows a good correspondence with Chron C3AN, and the dominantly normal polarity interval between 260 and 275 mbsf with Chron C4N. Larger uncertainties exist in the chronal assignments of the magnetozones beneath this depth. The distinctive long normal polarity interval that extends from about 357 (and possibly up to $339 \mathrm{mbsf}$ ) down to $406 \mathrm{mbsf}$, can be correlated only with Chron C5N. However, the overlying sequence of normal and reverse polarity magnetozones in the interval from 290 to 319 mbsf must then be correlated with the relatively short younger normal polarity interval of Chron C4AN. A possible explanation for the complex series of magnetozones in this interval is repetition of the sequence by downslope slumping (Site 704 is located in a topographic low on the Meteor Rise, and sporadic influx of material from the adjacent higher terrain is a distinct possibility).

Because of the existence of a stratigraphic hiatus at about 435 mbsf and the increasingly intermittent magnetostratigraphic record beneath this, no other confident chronal assignment can be made. However, within the resolution of the biostratigraphic data, Chron C5DN is tentatively identified in the interval 490 499 mbsf and the older boundary of the distinctive long normal polarity Chron C6N at a depth of about 590 mbsf.

\section{DISCUSSION AND CONCLUSIONS}

Paleomagnetic investigation of the middle Eocene to Pleistocene sediments recovered from Sites 703 and 704 on the Meteor Rise indicates the presence of a stable characteristic component of magnetization in the majority of sediments, which appears to represent a reliable record of the succession of geomagnetic polarity reversals during this interval. There is evidence that the declination of the characteristic magnetization of the majority of the discrete paleomagnetic samples taken from the upper 150-m section of Holes 704A and 704B has been modified significantly during the subsampling process. The horizontal component of the magnetization in these samples is systematically directed perpendicular to the split face of the sediment core. Because these sites are situated at relatively high magnetic latitudes the horizontal component of the geomagnetic field is relatively weak, and consequently, the degree of alignment of the magnetic moments of the grains along the magnetic meridian is likely to be much less than the degree of alignment in a vertical sense (downward for reverse polarity and upward for normal polarity). It appears that the insertion of the $6-\mathrm{cm}^{3}$ rectangular paleomagnetic sample boxes into the soft and water-saturated cores results in the application of a shear parallel with the "push axis." This shear produces a mechanical realignment of a significant proportion of the magnetic mineral grains, thus imparting a component of remanence along this axis. This effect has been documented in previous paleomagnetic studies of soft glacial clays (Gravenor et al., 1984) and recent marine sediments sampled by gravity and piston corers (Hailwood et al., 1989) but this is believed to be the first recorded observation of the effect in ODP sediment cores.

The effect is only present in the relatively soft and watersaturated sediments cored with the APC system in the upper $150 \mathrm{~m}$ of Holes $704 \mathrm{~A}$ and 704B. It was not observed in the stiffer sediments cored with the XCB at greater depths in these holes or in the relatively compacted early Miocene to middle Eocene age sediments cored in Hole 703.

Despite this major modification of the (relatively weak) horizontal component of magnetization, the much stronger vertical component, on which the polarity assignments are based, appears to be unaffected by the subsampling process. Consequently, the polarity determinations made on these samples are considered to be reliable.

The combination of whole-core and discrete sample paleomagnetic determinations on the middle Eocene to early Miocene age sediments recovered at Site 703 and the early Miocene to Pleistocene age sediments at Site 704 together provide a remarkably complete magnetostratigraphic record for the Meteor Rise region, spanning much of the last $40 \mathrm{~m} . \mathrm{y}$. The correlation of this record to the GPTS is generally good for the Oligocene and late Miocene to Pleistocene, but is poorer and in some cases tentative for parts of the early and middle Miocene. The principal magnetostratigraphic datums defined at the two sites are listed in Tables 4 and 5 .

The combined magnetostratigraphic record for these two sites provides a basis for the development of refined high-latitude 


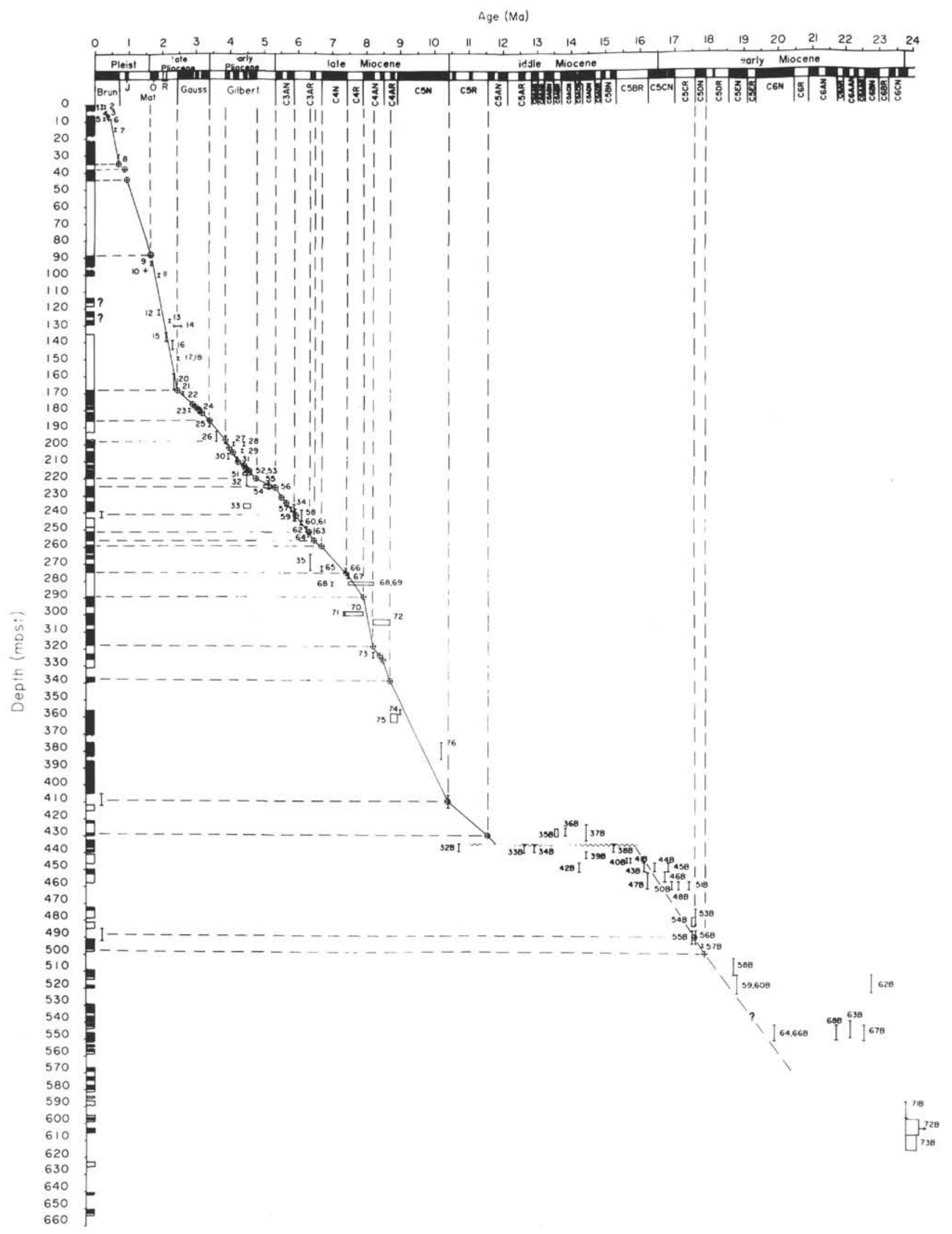

Figure 14. Correlation of the magnetic polarity reversal record for Site 704 with the GPTS of Berggren et al. (1985). The polarity sequence above $220 \mathrm{mbsf}$ was defined primarily from Hole 704A, and that below from Hole 704B. The numbered biostratigraphic datums used to constrain this correlation are listed in Table 3; the codes with the letter $B$ are from Ciesielski, Kristoffersen, et al. (1988, p. 641). 
Table 3. Biostratigraphic datums, Site 704.

\begin{tabular}{|c|c|c|c|}
\hline Code & Datum $^{\mathrm{a}}$ & Age (Ma) & $\begin{array}{c}\text { Depth range } \\
\text { (mbsf) }\end{array}$ \\
\hline \multicolumn{4}{|c|}{ Hole $704 \mathrm{~A}$} \\
\hline 1 & LAAD Hemidiscus karstenii (D) & 0.192 & $0.00-2.28$ \\
\hline 2 & LAD Globorotalia crassaformis (F) & $0.27-0.30$ & $0.74-2.20$ \\
\hline 3 & LAD Stylatractus universus $(\mathrm{R})$ & 0.410 & $6.50-7.20$ \\
\hline 4 & FAAD Hemidiscus karstenii in Quaternary (D) & 0.410 & $6.80-7.92$ \\
\hline 5 & FAD Globorotalia truncatulinoides $(\mathrm{F})$ & $0.27-0.30$ & $7.88-9.30$ \\
\hline 6 & LAD Pseudoemiliania lacunosa $(\mathrm{N})$ & $0.40-0.474$ & $8.55-8.75$ \\
\hline 7 & LAD Atinocyclus ingens (D) & 0.62 & $14.40-15.90$ \\
\hline 8 & LAD Globorotalia puncticulata puncticulata $(\mathrm{F})$ & 0.73 & $29.92-34.08$ \\
\hline 9 & LAD Clathrocyclas bicornis $(\mathrm{R})$ & 1.66 & $92.70-94.60$ \\
\hline 10 & LAD Rhizosolenia barboi (D) & 1.50 & $97.90-98.00$ \\
\hline 11 & LAD Coscinodiscus kolbei (D) & 1.89 & $99.52-101.00$ \\
\hline 12 & LAD Eucyrtidium calvertense (R) & 1.90 & $121.20-123.30$ \\
\hline 13 & LAD Thalassiosira convexa (D) & 2.20 & $126.52-128.00$ \\
\hline 14 & FCO Cycladophora davisian (R) & $2.6-2.8$ & $129.78-131.30$ \\
\hline 15 & LAAD (>5\%) Coscinodiscus vulnificus (D) & 2.12 & $134.52-139.00$ \\
\hline 16 & LAAD $(>10 \%)$ Coscinodiscus vulnificus (D) & 2.29 & $139.02-144.00$ \\
\hline 17 & LAD Helotholus vema $(\mathrm{R})$ & 2.47 & $148.90-150.30$ \\
\hline 18 & LAD Desmospyris spongiosa $(\mathbf{R})$ & 2.47 & $148.90-150.30$ \\
\hline 19 & FCO Globorotalia inflata $(\mathrm{F})$ & & $150.44-151.90$ \\
\hline 20 & Top NN17 Zone (N) & 2.35 & $158.91-168.04$ \\
\hline 21 & LAAD (>10\%) Cosmiodiscus insignis (D) & 2.49 & $167.48-169.30$ \\
\hline 22 & LAAD $(>5 \%)$ Nitzschia weaveri (D) & 2.63 & $169.32-170.80$ \\
\hline 23 & LAD Nitzschia interfrigidaria (D) & 2.81 & $179.02-180.50$ \\
\hline 24 & FAD Coscinodiscus vulnificus (D) & 3.10 & $179.02-180.50$ \\
\hline 25 & LAD Globorotalia margaritae (F) & 3.40 & $187.82-189.30$ \\
\hline 26 & FAD Thalassiosira convexa $\mathrm{v}$. aspinosa (D) & 3.60 & $192.72-198.01$ \\
\hline 27 & FAD Globorotalia crassaformis $(\mathrm{F})$ & 4.10 & $199.13-200.59$ \\
\hline 28 & FAD Globorotalia puncticulata puncticulata $(\mathrm{F})$ & 4.40 & $199.13-200.59$ \\
\hline 29 & FAD Nitzchia interfrigidaria (D) & 4.02 & 203.11-204.01 \\
\hline 30 & FAD Helotholus vema $(\mathrm{R})$ & 3.95 & $205.33-208.60$ \\
\hline 31 & FAD Nitzschia angulata (D) & 4.22 & $207.52-209.00$ \\
\hline 32 & LAD Denticulopsis hustedtii (D) & 4.48 & $213.60-224.31$ \\
\hline 33 & LAD Stichocorys peregrina $(\mathrm{R})$ & 4.4-4.6 & $234.24-237.24$ \\
\hline 34 & Top Cosmiodiscus insignis v. triangula acme (D) & $5.87-5.92$ & $235.20-244.76$ \\
\hline 35 & Base Cosmiodiscus insignis v, triangula acme (D) & $6.32-6.42$ & $263.91-273.37$ \\
\hline \multicolumn{4}{|c|}{ Hole 704B } \\
\hline 51 & LAD Denticulopsis hustedtii (D) & 4.48 & $213.60-214.50$ \\
\hline 52 & LAD Stichocorys peregrina (R) & $4.4-4.6$ & $216.20-217.98$ \\
\hline 53 & LAD Amphymenium challengerae $(\mathrm{R})$ & 4.35 & $216.20-217.98$ \\
\hline 54 & FAD Globorotalia sphericomiozea (F) & $5.01-5.24$ & $223.40-224.90$ \\
\hline 55 & FAD Thalassiosira oestrupii (D) & $5.10-5.20$ & $221.92-224.00$ \\
\hline 56 & Cosmiodiscus insignis v, triangula (isolated) (D) & 5.38 & 225.50 \\
\hline 57 & LAD Thalassiosira praeconvexa (D) & 5.80 & $236.52-238.00$ \\
\hline 58 & LAD Thalassiosira convexa $\mathrm{v}$. aspinosa (D) & 6.10 & $238.02-244.80$ \\
\hline 59 & Top Cosmiodiscus insignis v. triangula acme (D) & 5.87 & $238.02-244.80$ \\
\hline 60 & FAD Amphymenium challengerae $(\mathrm{R})$ & 6.09 & $244.97-247.20$ \\
\hline 61 & LAD Lamprocyclas aegles group (R) & 6.09 & $244.97-247.20$ \\
\hline 62 & LAD Didymocyrtis sp. A (R) & 6.25 & $247.97-250.92$ \\
\hline 63 & Base Cosmiodiscus insignus v, triangula acme (D) & 6.42 & $250.82-251.40$ \\
\hline 64 & FAD Thalassiosira praeconvexa (D) & 6.30 & $252.51-253.99$ \\
\hline 65 & LAD Nitzschia porteri (D) & 6.70 & $271.52-273.00$ \\
\hline 66 & FAD Lamprocyclas aegles group (R) & 7.40 & $272.65-275.65$ \\
\hline 67 & FAD Didymocyrtis sp. A (R) & 7.47 & $275.65-278.15$ \\
\hline 68 & LAD Diartus hughesi $(\mathrm{R})$ & $7,7.46-8.20$ & $280.20-282.15$ \\
\hline 69 & FAD Stichocorys peregrina $(\mathbf{R})$ & $7.46-8.20$ & $280.20-282.15$ \\
\hline 70 & FAD Nitzschia marina $(\mathrm{D})$ & $7.41-7.90$ & $298.02-300.00$ \\
\hline 71 & FAD Nitzchia reinholdii (D) & 7.41 & $298.02-300.00$ \\
\hline 72 & LAD Denticulopsis lauta (D) & $8.25-8.70$ & $303.02-306.00$ \\
\hline 73 & FAD Nitzschia fossilis (D) & 8.20 & $322.02-325.00$ \\
\hline 74 & FAD Diartus hughesi (R) & 9.00 & $356.20-358.10$ \\
\hline 75 & FAD Hemidiscus cuneiformis (D) & $\sim 8.7-8.9$ & $358.50-363.00$ \\
\hline 76 & FAD Neogloboquadrina acostaensis (F) & 10.20 & $375.20-384.70$ \\
\hline 77 & FAD Asteromphalus sp. 1 (D) & $\sim 8.7-8.9$ & $387.02-392.57$ \\
\hline 78 & LAD Cyrtocapsella japonica (R) & $\sim 8.7-9.1$ & $389.76-392.33$ \\
\hline 79 & FAD Denticulopsis dimorpha (D) & 8.9 & $392.59-397.13$ \\
\hline 80 & FAD Cyrtocapsella japonica (R) & 12.00 & $415.31-422.70$ \\
\hline 81 & FAD Hemidiscus cuneiformis (D) & 11.2 & $425.02-426.50$ \\
\hline 82 & FAD Cyrtocapsella tetrapera $(\mathbf{R})$ & 11.4 & $424.79-427.79$ \\
\hline
\end{tabular}

Note: Biostratigraphic datums are plotted by code in Figure 14. Detailed discussion of these datums is found in Müller et al. (this volume).

${ }^{a} \mathrm{D}=$ diatom $; \mathrm{R}=$ radiolarian; $\mathrm{N}=$ nannofossil; $\mathrm{F}=$ foraminifer $\mathrm{LAD}=$ last-appearance datum; $\mathrm{FAD}=$ first- appearance datum; LAAD = last absolute appearance datum; FAAD $=$ first absolute appearance datum; $\mathrm{FCO}=$ first common appearance. 
Table 4. Principal paleomagnetic datums, Hole 703A.

\begin{tabular}{llllr}
\hline \multicolumn{1}{c}{ Datum } & $\begin{array}{c}\text { Age }^{\mathrm{a}} \\
\text { (Ma) }\end{array}$ & $\begin{array}{c}\text { Bracketing samples } \\
\text { (core, section, } \\
\text { interval in cm) }\end{array}$ & $\begin{array}{c}\text { Depth range } \\
\text { (mbsf) }\end{array}$ & $\begin{array}{c}\text { Mean } \\
\text { position } \\
\text { (mbsf) }\end{array}$ \\
\hline C6BN/C6BR (?) & 22.97 & $4 \mathrm{H}-5,135 / 4 \mathrm{H}-6,5$ & $31.25-31.45$ & 31.35 \\
C6BR/C6CN (?) & 23.27 & $4 \mathrm{H}-6,115 / 4 \mathrm{H}-6,125$ & $32.54-32.64$ & 32.59 \\
C6CN/C6CR & 24.21 & $6 \mathrm{H}-2,135 / 6 \mathrm{H}-3,35$ & $45.74-46.24$ & 45.99 \\
C6CR/C7N & 25.50 & $6 \mathrm{H}-7,65 / 7 \mathrm{H}-2,5$ & $52.54-53.95$ & 53.24 \\
C10N/C10R & 30.33 & $8 \mathrm{H}-3,95 / 8 \mathrm{H}-3,104$ & $65.84-65.94$ & 65.89 \\
C10R/C11N & 31.23 & $9 \mathrm{H}-5,85 / 9 \mathrm{H}-5,104$ & $78.24-78.44$ & 78.34 \\
C11N/C11R & 32.06 & $10 \mathrm{H}-3,111 / 10 \mathrm{H}-5,15$ & $85.00-87.05$ & 86.02 \\
C11R/C12N & 32.46 & $10 \mathrm{H}-6,125 / 11 \mathrm{H}-2,45$ & $89.64-92.34$ & 90.99 \\
C12N/C12R & 32.90 & $11 \mathrm{H}-4,45 / 11 \mathrm{H}-4,125$ & $95.34-96.14$ & 95.74 \\
C13R/C15N (?) & 37.24 & $15 \mathrm{H}-2,75 / 15 \mathrm{H}-2,85$ & $130.65-130.75$ & 130.70 \\
\hline
\end{tabular}

${ }^{\text {a }}$ Chron boundary ages proposed by Berggren et al. (1985).

biostratigraphic zonation schemes and for their chronometric calibration. These aspects are developed in the associated paper by Müller et al. (this volume). The magnetostratigraphy also provides an important time calibration for defining the periodicity of the late Neogene carbonate and stable isotope fluctuations observed in these cores and relating these fluctuations to the paleoceanographic and paleoclimatic driving forces.

\section{ACKNOWLEDGMENTS}

We would like to express our appreciation to the many people who have contributed to the success of this work. These include the officers, crew, and drilling engineers of JOIDES Resolution, the ODP shipboard technical support team (particularly Skip Hutton and Kevin Rogers for help with the shipboard paleomagnetic measurements), and our colleagues in the Leg 114 shipboard scientific party. We are grateful to Kevin Padley for considerable help with the post-cruise paleomagnetic measurements and to Kate Saull and Christine Tresise, respectively, for their care and patience in drafting the figures and typing the manuscript.

\section{REFERENCES}

Berggren, W. A., Kent, D. V., and Flynn, J. J., 1985. Jurassic to Paleogene: part 2. Paleogene geochronology and chronostratigraphy. In Snelling, N. J. (Ed.), The Chronology of the Geological Record: Geol. Soc. London Mem., 10:141-195.

Ciesielski, P. F., Kristoffersen, Y., et al., 1988. Proc. ODP, Init. Repts., 114: College Station, TX (Ocean Drilling Program).

Gravenor, C. P., Symons, D.T.A., and Coyle, D. A., 1984. Errors in the anisotropy of magnetic susceptibility and magnetic remanence of unconsolidated sediments produced by sampling methods. Geophys. Res. Lett., 1:836-829.

Hailwood, E. A., Stumpp, C., and Zukin, J., 1989. Soft sediment sampling errors in palaeomagnetic and magnetic fabric data. Bull. Int. Assoc. Geomagn. Aeron., 53:199. (Abstract)

LaBrecque, J. L. (Ed.), 1986. South Atlantic Ocean and Adjacent Continental Margin, Atlas 13: Ocean Margin Drilling Program Reg. Atlas Ser., 13.

LaBrecque, J. L., and Hayes, D. E., 1979. Seafloor spreading history of the Agulhas Basin. Earth Plant. Sci. Lett., 45:411-428.

Lawver, L. A., Sclater, J. G., and Meinke, L., 1985. Mesozoic and Cenozoic reconstructions of the South Atlantic. Tectonophysics, 114:233-254.

Løvlie, R., Markussen, B., Sejrup, H. P., and Thiede, J., 1986. Magnetostratigraphy in three Arctic Ocean sediment cores; argument for geomagnetic excursions within oxygen-isotope stage 2-3. Phys. Earth Planet. Int., 43:173-184.

Wise, S. W., 1983. Mesozoic and Cenozoic calcareous nannofossils recovered by Deep Sea Drilling Project Leg 71 in the Falkland Plateau region, southwest Atlantic Ocean. In Ludwig, W. J., Krasheninnikov, V. A., et al., Init. Repts. DSDP, 71: Washington (U.S. Govt. Printing Office), 481-550.

Zijderveld, J.D.A., 1967. AC demagnetization of rocks: analysis of results. In Collinson, D. W., Creer, K. M., and Runcorn, S. K. (Eds.), Methods in Palaeomagnetism: New York (Elsevier), 254286.

Date of initial receipt: 1 June 1989

Date of acceptance: 17 January 1990

Ms 114B-186 
Table 5. Principal paleomagnetic datums, Site 704.

\begin{tabular}{|c|c|c|c|c|}
\hline Datum $^{\mathrm{a}}$ & $\begin{array}{l}\text { Age } \\
\text { (Ma) }\end{array}$ & $\begin{array}{l}\text { Bracketing samples } \\
\text { (interval in } \mathrm{cm} \text { ) }\end{array}$ & $\begin{array}{l}\text { Depth range } \\
\text { (mbsf) }\end{array}$ & $\begin{array}{c}\text { Mean position } \\
\text { (mbsf) }\end{array}$ \\
\hline Brunhes/Matuyama & 0.73 & $704 \mathrm{~B}-4 \mathrm{H}-6,6 / 5 \mathrm{H}-1,57$ & $33.26-35.77$ & $34.51 \pm 1.25$ \\
\hline Jaramillo $(y)$ & 0.91 & $704 \mathrm{~B}-5 \mathrm{H}-2,132 / 5 \mathrm{H}-3,61$ & $38.02-38.81$ & $38.41 \pm 0.39$ \\
\hline Jaramillo (o) & 0.98 & 704 B-5H-6, 100/704A-5H-7, 16 & $43.70-44.85$ & $44.27 \pm 0.57$ \\
\hline Olduvai $(y)$ & 1.66 & $704 \mathrm{~A}-10 \mathrm{H}-4,100 / 10 \mathrm{H}-5,31$ & $88.69-89.50$ & $89.09 \pm 0.40$ \\
\hline Matuyama/Gauss & 2.47 & $704 \mathrm{~A}-18 \mathrm{X}-6,145 / 19 \mathrm{X}-1,5$ & $168.15-168.75$ & $168.45 \pm 0.30$ \\
\hline Kaena $(y)$ & 2.92 & $704 A-19 X-5,126 / 19 X-6,5$ & $175.95-176.25$ & $176.10 \pm 0.15$ \\
\hline Kaena (o) & 2.99 & $704 \mathrm{~A}-19 \mathrm{X}-7,5 / 19 \mathrm{X}-7,15$ & $177.75-177.85$ & $177.80 \pm 0.05$ \\
\hline Mammoth (y) & 3.08 & $704 \mathrm{~A}-20 \mathrm{X}-1,85 / 20 \mathrm{X}-1,95$ & $179.05-179.15$ & $179.10 \pm 0.05$ \\
\hline Mammoth (o) & 3.18 & $704 \mathrm{~A}-20 \mathrm{X}-3,15 / 20 \mathrm{X}-3,45$ & $181.35-181.65$ & $181.50 \pm 0.15$ \\
\hline Gauss/Gilbert & 3.40 & $704 \mathrm{~A}-20 \mathrm{X}-6,84 / 20 \mathrm{X}-6,104$ & $186.54-186.74$ & $186.64 \pm 0.10$ \\
\hline Cochiti (y) & 3.88 & $704 \mathrm{~A}-22 \mathrm{X}-1,115 / 22 \mathrm{X}-2,5$ & $198.35-198.75$ & $195.55 \pm 0.20$ \\
\hline Cochiti (o) & 3.97 & $704 \mathrm{~A}-22 \mathrm{X}-4,14 / 22 \mathrm{X}-4,34$ & $201.84-202.04$ & $201.94 \pm 0.10$ \\
\hline Nunivak (y) & 4.10 & $704 \mathrm{~A}-22 \mathrm{X}-5,94 / 22 \mathrm{X}-5,104$ & $204.14-204.24$ & $204.19 \pm 0.05$ \\
\hline Nunivak (o) & 4.24 & $704 \mathrm{~A}-23 \mathrm{X}-3,55 / 23 \mathrm{X}-3,75$ & $210.25-210.45$ & $210.35 \pm 0.10$ \\
\hline Sidufjall (y) & 4.40 & $704 \mathrm{~A}-23 \mathrm{X}-4,74 / 23 \mathrm{X}-4,84$ & $211.94-212.04$ & $211.99 \pm 0.05$ \\
\hline Sidufjall (o) & 4.47 & $704 \mathrm{~A}-23 \mathrm{X}-5,44 / 23 \mathrm{X}-5,64$ & $213.14-213.34$ & $213.24 \pm 0.10$ \\
\hline Thvera $(y)$ & 4.57 & $704 \mathrm{~A}-23 \mathrm{X}-6,10 / 24 \mathrm{X}-1,33$ & $214.29-216.52$ & $215.40 \pm 1.11$ \\
\hline Thvera (o) & 4.77 & $704 \mathrm{~A}-24 \mathrm{X}-3,14 / 24 \mathrm{X}-3,34$ & $219.64-219.84$ & $219.74 \pm 0.10$ \\
\hline Gilbert/C3AN & 5.35 & $704 \mathrm{~B}-25 \mathrm{X}-1,153 / 25 \mathrm{X}-2,28$ & $224.55-224.97$ & $224.76 \pm 0.21$ \\
\hline C3AN.33 & 5.53 & $704 \mathrm{~B}-25 \mathrm{X}-6,24 / 25 \mathrm{X}-6,44$ & $230.94-231.14$ & $231.04 \pm 0.10$ \\
\hline C 3 AN. 61 & 5.68 & $704 \mathrm{~B}-26 \mathrm{X}-1,104 / 26 \mathrm{X}-1,124$ & $233.74-233.94$ & $233.84 \pm 0.10$ \\
\hline C $3 \mathrm{AN} / \mathrm{C} 3 \mathrm{AR}$ & 5.89 & $704 \mathrm{~B}-26 \mathrm{X}-5,45 / 27 \mathrm{X}-2,41$ & $239.14-244.10$ & $241.62 \pm 2.48$ \\
\hline C3AR.59 & 6.37 & $704 \mathrm{~B}-27 \mathrm{X}-6,135 / 27 \mathrm{X}-7,2$ & $251.05-251.45$ & $251.25 \pm 0.20$ \\
\hline C3AR.75 (?) & 6.50 & $704 \mathrm{~B}-28 \mathrm{X}-4,45 / 28 \mathrm{X}-4,65$ & $256.65-256.85$ & $256.75 \pm 0.10$ \\
\hline C 3 AR/C $4 \mathrm{~N}(?)$ & 6.70 & $704 \mathrm{~B}-28 \mathrm{X}-6,25 / 28 \mathrm{X}-6,35$ & $259.45-259.55$ & $259.50 \pm 0.05$ \\
\hline $\mathrm{C} 4 \mathrm{~N} / \mathrm{C} 4 \mathrm{R}$ & 7.41 & $704 \mathrm{~B}-30 \times-4,55 / 30 \times-4,75$ & $275.75-275.95$ & $275.85 \pm 0.10$ \\
\hline $\mathrm{C} 4 \mathrm{R} / \mathrm{C} 4 \mathrm{AN}$ & 7.90 & $704 \mathrm{~B}-32 \mathrm{X}-1,35 / 32 \mathrm{X}-1,39$ & $290.05-290.08$ & $290.06 \pm 0.01$ \\
\hline C4AN.52 & 8.21 & 704B-35X-1, 25/35X-1, 45 & $318.45-318.65$ & $318.55 \pm 0.10$ \\
\hline C4AN. 85 & 8.41 & $704 \mathrm{~B}-35 \mathrm{X}-4,125 / 35 \mathrm{X}-5,5$ & $323.95-324.25$ & $324.10 \pm 0.15$ \\
\hline $\mathrm{C} 4 \mathrm{AN} / \mathrm{C} 4 \mathrm{AR}$ & 8.50 & $704 \mathrm{~B}-35 \mathrm{X}-6,115 / 35 \mathrm{X}-6,145$ & $326.85-327.15$ & $327.05 \pm 0.15$ \\
\hline C4AR. 50 (?) & 8.71 & $704 \mathrm{~B}-37 \mathrm{X}-1,61 / 37 \mathrm{X}-2,61$ & $337.80-339.30$ & $338.55 \pm 0.75$ \\
\hline C $5 \mathrm{~N} / \mathrm{C} 5 \mathrm{R}$ & 10.42 & $704 \mathrm{~B}-44 \mathrm{X}-2,54 / 45 \mathrm{X}-1,36$ & $405.73-413.55$ & $409.64 \pm 3.91$ \\
\hline C5R/CSAN & 11.55 & $704 \mathrm{~B}-46 \mathrm{X}-5,85 / 46 \mathrm{X}-5,95$ & $429.55-429.65$ & $429.60 \pm 0.05$ \\
\hline C5CR/C5DN & 17.57 & $704 \mathrm{~B}-53 \mathrm{X}-3,145 / 54 \mathrm{X}-2,15$ & $486.15-492.85$ & $489.50 \pm 3.35$ \\
\hline C5DN/C5DR(?) & 17.90 & $704 \mathrm{~B}-54 \mathrm{X}-5,95 / 54 \mathrm{X}-5,104$ & $498.15-398.25$ & $498.20 \pm 0.05$ \\
\hline
\end{tabular}

${ }^{a} y=$ young end of magnetic subchron, $o=$ old end. 